\title{
Reviewing energy system modelling of decentralized energy autonomy
}

By Jann Michael Weinand, Fabian Scheller and Russell McKenna

No. 41 | April 2020

\section{WORKING PAPER SERIES IN PRODUCTION AND ENERGY}

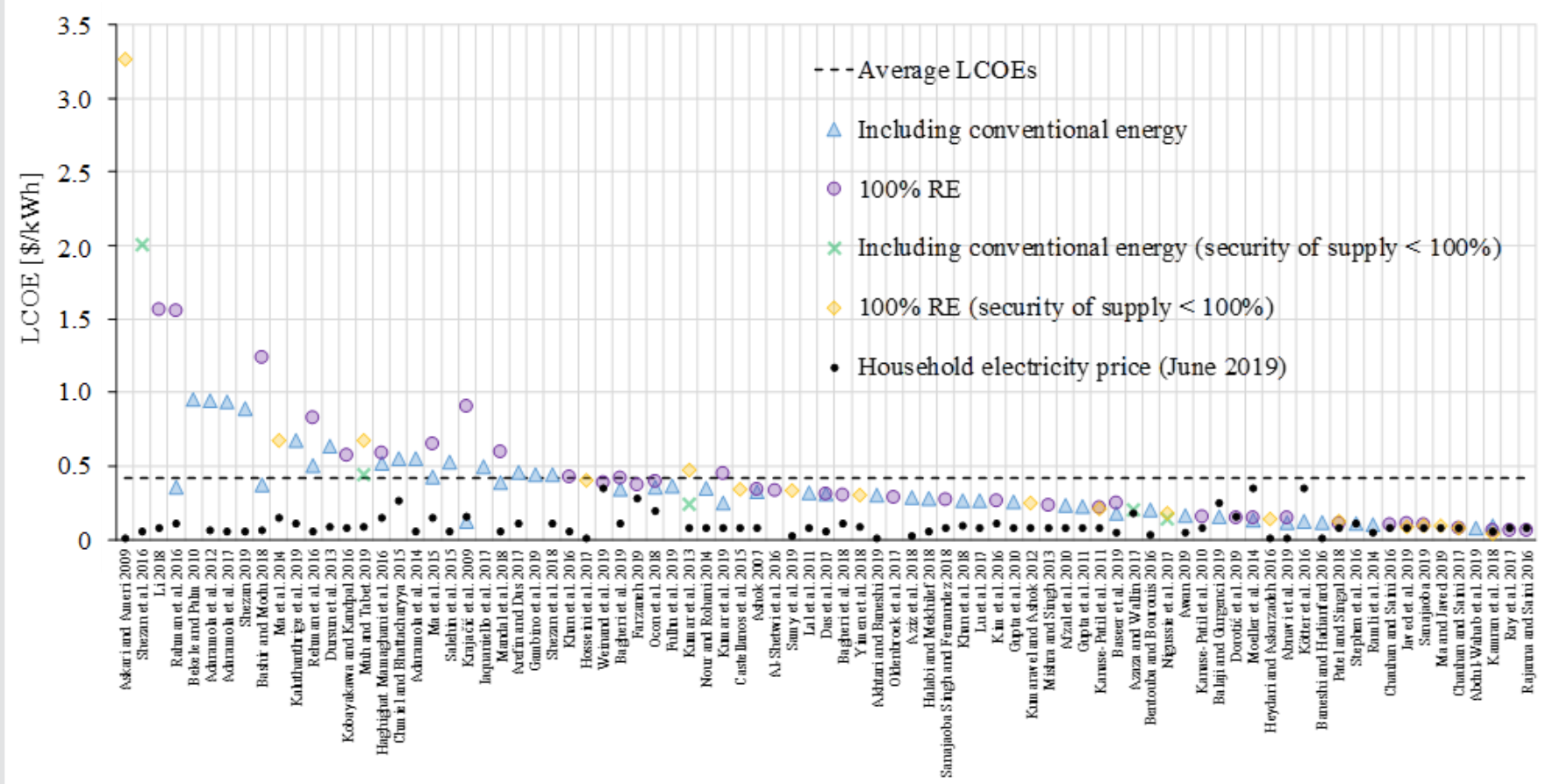




\title{
Reviewing energy system modelling of decentralized energy autonomy
}

\author{
Jann Michael Weinand'1, Fabian Scheller², Russell McKenna²
}

\author{
${ }^{1}$ Chair of Energy Economics, Institute for Industrial Production (IIP), \\ Karlsruhe Institute for Technology (KIT), Hertzstr. 16, 76187 Karlsruhe, \\ Germany \\ ${ }^{2}$ DTU Management, Technical University of Denmark, $2800 \mathrm{Kgs}$. Lyngby, \\ Denmark
}

Research attention on decentralized autonomous energy systems has increased exponentially in the past three decades, as demonstrated by the absolute number of publications and the share of these studies in the corpus of energy system modelling literature. This paper shows the status quo and future modelling needs for research on local autonomous energy systems. A total of 359 studies are roughly investigated, of which a subset of 123 in detail. The studies are assessed with respect to the characteristics of their methodology and applications, in order to derive common trends and insights. Most case studies apply to middle-income countries and only focus on the supply of electricity in the residential sector. Furthermore, many of the studies are comparable regarding objectives and applied methods. Local energy autonomy is associated with high costs, leading to levelized costs of electricity of $0.41 \$ / \mathrm{kWh}$ on average. By analysing the studies, many improvements for future studies could be identified: the studies lack an analysis of the impact of autonomous energy systems on surrounding energy systems. In addition, the robust design of autonomous energy systems requires higher time resolutions and extreme conditions. Future research should also develop methodologies to consider local stakeholders and their preferences for energy systems. 


\title{
Reviewing energy system modelling of decentralized energy autonomy
}

\author{
Jann Michael Weinand ${ }^{1}$, Fabian Scheller ${ }^{2}$, Russell McKenna ${ }^{2}$ \\ ${ }^{1}$ Chair of Energy Economics, Karlsruhe Institute of Technology, Hertzstraße 16, 76187 Karlsruhe, Germany \\ ${ }^{2}$ DTU Management, Technical University of Denmark, 2800 Kgs. Lyngby, Denmark \\ Corresponding author: Jann Michael Weinand, jann.weinand@ kit.edu, +49 72160844444
}

\begin{abstract}
Research attention on decentralized autonomous energy systems has increased exponentially in the past three decades, as demonstrated by the absolute number of publications and the share of these studies in the corpus of energy system modelling literature. This paper shows the status quo and future modelling needs for research on local autonomous energy systems. A total of 359 studies are roughly investigated, of which a subset of 123 in detail. The studies are assessed with respect to the characteristics of their methodology and applications, in order to derive common trends and insights. Most case studies apply to middle-income countries and only focus on the supply of electricity in the residential sector. Furthermore, many of the studies are comparable regarding objectives and applied methods. Local energy autonomy is associated with high costs, leading to levelized costs of electricity of $0.41 \$ / \mathrm{kWh}$ on average. By analysing the studies, many improvements for future studies could be identified: the studies lack an analysis of the impact of autonomous energy systems on surrounding energy systems. In addition, the robust design of autonomous energy systems requires higher time resolutions and extreme conditions. Future research should also develop methodologies to consider local stakeholders and their preferences for energy systems.
\end{abstract}

\section{Highlights}

- Literature review includes 123 studies about local autonomous energy systems.

- Common trends in method, objectives, technologies and perspective

- Homer and EnergyPlan simulation models are most common

- Levelized costs of electricity for local energy autonomy are $0.41 \$ / \mathrm{kWh}$ on average.

- Future work should focus on non-technical dimensions, open models and data

Keywords: Literature review, energy autonomy, off-grid systems, $100 \%$ renewable, energy system analysis, levelized cost of electricty, municipality, remote area 


\section{Introduction}

Between 1993 and 2017, the percentage of the worldwide population with access to electricity increased from 77\% to around $89 \%$ [1]. Since 2012, more than 100 million people per year have gained access to electricity. However, it is estimated that even in 2030 about 670 million people will still have no access to electricity [2]. Most people without access live in rural areas (84\%) and in sub-Saharan Africa or developing Asia (95\%) [3]. Negative examples include the developing countries of Burundi, Chad and Malawi, where less than $15 \%$ of the population have access to electricity [1]. Many of the newly electrified regions in developing countries apply off-grid solutions with diesel engines due to long distances to the national grid. Such completely energy autonomous systems are able to meet the energy demands of an entire community without energy imports [4].

Whereas these completely autonomous (i. e. off-grid) energy systems exist in developing countries mainly due to cost considerations, there are also efforts by municipalities and regions to become energy autonomous in industrialized countries with complete electrification (i.e. grid-connected). This is due to the energy transition and the related environmental awareness [5] as well as the desire of citizens to play an active role in energy supply and to be less dependent on central markets and structures (e. g. [6,7]). The majority of municipalities with energy autonomy aspirations strive for balanced energy autonomy and the focus is usually on electrical energy [5]. In this context, energy systems are balanced autonomous if they are energy neutral, i.e. the annual locally provided energy exceeds the annual demand [4]. In contrast to a completely energy autonomous solution, imports and exports are possible. In Germany, for example, municipal energy autonomy projects have increased exponentially since 1995 [8]. In 2017, 1,300 municipalities already participated in these projects, corresponding to $12 \%$ of all municipalities and $15 \%$ of the population in Germany [8].

Local energy autonomy can take different forms and degrees. In particular, autonomous energy systems need to exhibit the basic criteria as defined by Rae and Braedly [4]. First, the local system is able to generate at least as much energy to meet the demands. Second, the local system allows energy shifting possibilities for times in which there is a temporal mismatch between demand and supply (i.e. through storage or in the case of balanced autonomy through energy infrastructure). Third, the system is capable of operating independently on a stand-alone or offgrid basis. Thereby, local autonomy efforts are related to active participation of the community or rather the system components are owned by the community members. In general, autonomy efforts are directly related to the notion of self-governance and community ownership [4]. In this study, energy autonomy is defined the same way: it focusses on plants inside the municipality which tend to be operated by the local community, and may also include conventional technologies. However, due to the dependency on fuel transport and the high costs of diesel-based energy systems, a supply consisting at least in part of renewable energies could be worthwhile in these cases.

As the above examples demonstrate, balanced or completely autonomous energy systems are related to different objectives and have different effects on the local setting but possibly also on the overarching system. Due to the increasing relevance of local energy autonomy (c.f. section 3), there is a need to elaborate and define transition process aspects and successful transition pathways. Therefore, the aim of this study is to review the literature on local energy autonomy, i.e. in villages, districts, municipalities and regions, in order to identify the current state of the art and gaps or starting points for future studies. This spatial resolution is chosen since similar conditions 
apply, for example from a technical point of view (decentralised energy technologies) but also from a social point of view, such as the number and type of stakeholders. Studies on individual buildings and larger regions such as entire nations are therefore excluded. In contrast to the multitude of existing reviews, this paper for the first time shows a comprehensive overview and quantitative analysis of applied methods in energy autonomy case studies at the local level (cf. section 2).

This paper is structured as follows: section 2 gives an overview of already published literature reviews about energy system analyses with a focus on decentralized energy autonomy. Subsequently, section 3 presents the methodology for the literature search. Section 4 then presents and discusses the most important findings from the analysis of the literature, before the studies are critically assessed in section 5. A summary and conclusions are given in section 6 .

\section{Existing literature reviews}

Some review papers have already examined studies on local energy system planning for larger (e.g. urban areas) $[9,10]$ and smaller regions (e.g. municipalities / communities) [4,11-17]. In some cases, the focus is on some form of energy autonomy $[4,11,16,17]$, or this topic is at least briefly discussed [12,15]. A few other review papers [1821] discuss energy autonomy, but do not focus on the local level as defined in section 1 . This section now gives an overview about these existing literature reviews.

Even though there are some undeniable differences regarding the motives of local energy autonomy efforts in developed and developing countries, due to the growing utilization of decentralized renewable-based energy generators local energy autonomy projects also represent a business opportunity in industrialized countries according to the review of Engelken et al. [22]. Despite all of the criticism voiced by Heard et al. [20], the feasibility and viability of such local renewable energy systems have been also demonstrated in various studies as shown in the reviews of Brown et al. [18] and Hansen et al. [19].

In this context, a strategy to achieve this feasibility requires the discussion of crucial factors regarding energy autonomy. Kaundinya and Ravindranath [17] present both general success and failure stories of corresponding autonomy projects. According to the authors, a generalized approach to assess the suitability of off-grid and gridconnected systems, based on techno-economic-financial-environmental feasibility does not find adequate coverage in the literature yet. A comprehensive balance between grid-connected and off-grid (i.e. completely autonomous) systems also requires higher and combined efforts from policy makers and modelling experts. Issues and trends shaping local energy systems are conceptually summarized by Keirstead et al. [9] and Koirala et al. [12]. Concerning this matter, local energy systems fit very well into the neo-liberal ideas of self-reliance and independence [12]. A shift towards local autonomous systems, however, is not only associated with a host of social, financial and environmental benefits. Key challenges are the degree and scale of energy autonomy, the matching of demand with supply, the importance of socio-economic and political factors and the structural requirements in remote communities [12].

These results go in line with the findings of the review of Rae and Bradley [4]. While taking into account the different drivers of balanced or completely autonomous energy projects, the review investigates environmental, 
political, economic, technical and social concerns. Even though generation and utilization of renewable energy is primarily a technical challenge, social and political aspects are the most important factors in its implementation in the community. The conceptual framework of energy autonomy by Müller et al. [16] shares a similar focus: the involvement and motivation of administrations and community stakeholders are decisive for the successful transition towards local energy autonomy. According to Rae and Bradley [4], future projects should rely on successful autonomy projects since they might provide valuable lessons of the impact of positive social engagement and community involvement. In this context, especially island and remote community projects have shown that a shift towards a more autonomous and sustainable energy system is achievable.

Additionally, ensuring stable supply and reliability against all plausible outcomes in renewable energy availability might raise cost and complexity of the systems due to the impacts of worst-case conditions [20]. Distributed energy generation as with local autonomous projects encompasses a wide variety of technologies which tend to be highly sensitive to the deployment context [15]. Thus, it is important to consider the necessary spatial and temporal boundaries of the region or community. This includes regional features but also limitation of regional resources not only with respect to wind or solar. In this context, Heard et al. [20] point out that special attention should be paid to the potential disruption to rivers and associated habitats from hydro-electricity as well as to the increasing dependency on biomass and associated reorganization of farming.

Some of the mentioned aspects have also been posed in terms of future modelling needs. Trans-disciplinary and multi-dimensional features of low-carbon community model approaches are outlined by Nakata et al. [21]: models should consider e.g. the utilization of waste for energy, the penetration of clean coal technologies, the inclusion of various sectors, and approaches related to energy-for-development issues in rural areas of developing countries. Dependent on the objectives and constraints, Gamarra and Guerrero [11] point out innovative planning guidelines by reviewing optimization techniques applied to microgrid planning. While the microgrid siting problem of autonomous systems requires robust methodologies, the operation of the autonomous system is only possible with reliable energy management systems. Thereby, stochastic optimization could be one solution for a more realistic estimate [17]. Furthermore, computer-based techno-economic assessment tools of grid-connected and off-grid systems should be combined with methods of material flow analysis or life cycle assessment [17]. Besides, Scheller and Bruckner [13] present requirements for energy system modelling at the municipal level and discuss existing optimization models concerning their fundamental approaches. Finally, they provide future modelling needs for successful energy system analyses which are also linked with the mentioned challenges of autonomy projects. Further general assessments of available methods and tools but also opportunities for future energy system planning at the community level are presented by Huang et al. [14] and Mirakyan and De Guio [10].

In contrast to many other literature reviews, the present paper presents a comprehensive overview and quantitative analysis of applied methods in case studies on energy autonomous systems at the local level. Of the reviews discussed in this section, only $[4,11,12,15-17]$ focus on energy autonomy at the local level. Of these six papers, only Kaudinya et al. [17] and Gamarra et al. [11] concentrate on methodological aspects. However, the studies differ from the present review study by concentrating on the comparison of grid-connected and off-grid energy systems [17] or only on microgrid studies [11]. Furthermore, the studies are from 2009 [17] and 2015 [11], 
respectively, and since then, the published articles on local energy autonomy have more than doubled (cf. section 3). Apart from the general topic, this review also covers new aspects such as a compilation of costs for local energy autonomous systems (cf. section 4.7).

\section{Review methodology}

The literature on local energy system analysis has increased exponentially from 1990 until 2019 (cf. Figure 1), along with the local energy autonomy efforts described in section 1 . Scopus ${ }^{1}$ was used for the primary literature search, since it covers a wider range of journals [23] as well as more recent sources [24] than other databases like Web of Science. The initial search query in Table 1 results in a total of 2,453 studies (cf. bright part of the search query and bright curve in Figure 1). The search query contains the methodology (e. g. energy system analysis or simulation), the spatial resolution (e. g. municipality or region) and the restriction that it is a peer-reviewed article. $359(15 \%)$ of the 2,453 studies on local energy system analyses deal with autonomous energy systems and have also exponentially increased in recent years (Adjusted search in Table 1 and dark part of search query and diagram in Figure 1).

Table 1: Different search queries for the literature search in Scopus. Included are publications, which were published between 1990 and 2019.

\begin{tabular}{|c|c|c|}
\hline Search name & Search query & Number of studies \\
\hline Initial search & $\begin{array}{l}\text { TITLE-ABS-KEY ("energy system" AND ("simulation" OR "modelling" OR } \\
\text { "optimisation" OR "analysis") AND ("region" OR "municipalities" OR } \\
\text { "municipality" OR "communities" OR "community" OR ("district" AND } \\
\text { NOT "district heating") OR "city" OR "cities" OR "town" OR "remote")) } \\
\text { AND (LIMIT-TO (DOCTYPE,"ar")) }\end{array}$ & 2,453 \\
\hline Adjusted search & $\begin{array}{l}\text { TITLE-ABS-KEY ("energy system" AND ("simulation" OR "modelling" OR } \\
\text { "optimisation" OR "analysis") AND ("region" OR "municipalities" OR } \\
\text { "municipality" OR "communities" OR "community" OR ("district" AND } \\
\text { NOT "district heating") OR "city" OR "cities" OR "town" OR "remote") } \\
\text { AND ("off-grid" OR "off grid" OR ("100\%" AND "RE") OR ("100\%" AND } \\
\text { "renewable") OR "100\%-renewable" OR ("energy" AND "autonomy") OR } \\
\text { ("energy" AND "autarky") OR ("energy" AND "self-sufficiency") OR } \\
\text { ("energy" AND "self-sufficient") OR "energy independent" OR "stand- } \\
\text { alone" OR "energy autonomous" OR "island system")) AND (LIMIT-TO } \\
\text { (DOCTYPE,"ar")) }\end{array}$ & 359 \\
\hline $\begin{array}{l}\text { "Energy system analysis" } \\
\text { search }\end{array}$ & $\begin{array}{l}\text { TITLE-ABS-KEY("energy system" AND ("simulation" OR "modelling" OR } \\
\text { "optimisation" OR "analysis")) AND (LIMIT-TO(DOCTYPE,"ar")) }\end{array}$ & 12,368 \\
\hline
\end{tabular}

The increasing importance of the topics could be only related to the generally exponentially increasing number of publications. However, the share of local energy system analyses in the field of energy system analysis (Energy system analysis search in Table 1) has increased from 8\% (1990) to 20\% (2019) and that of local energy autonomous systems from $0 \%$ to $3 \%$.

The 359 studies about local energy autonomy were examined for suitability for this review. 236 studies were excluded for the reasons outlined in Table 2. For 122, most of them were excluded because of an unsuitable spatial resolution (e.g. energy system analysis of a single building). A total of 123 studies remained ([8,25-146]), which were mainly published in the journals Energy and Renewable Energy (cf. Table 3). In addition, Table 4 shows the ten most globally cited articles on local energy autonomy.

\footnotetext{
1 https://www.scopus.com/search/form.uri?display=basic
} 
Table 2: Studies that resulted from the adjusted search in Scopus and are not considered in this literature review for the reasons given in the table.

\section{Exclusion criterium}

The study does not consider energy autonomy as defined in section 1 (i. e. at least balanced autonomy has to be analysed)

Autonomy is considered in a different context than energy

Autonomy is only mentioned as a future target in the paper

The spatial resolution of the study does not match our definition of local energy systems (cf. section 1)

- $\quad$ Single consumer / households / building

- $\quad$ Single commercial application

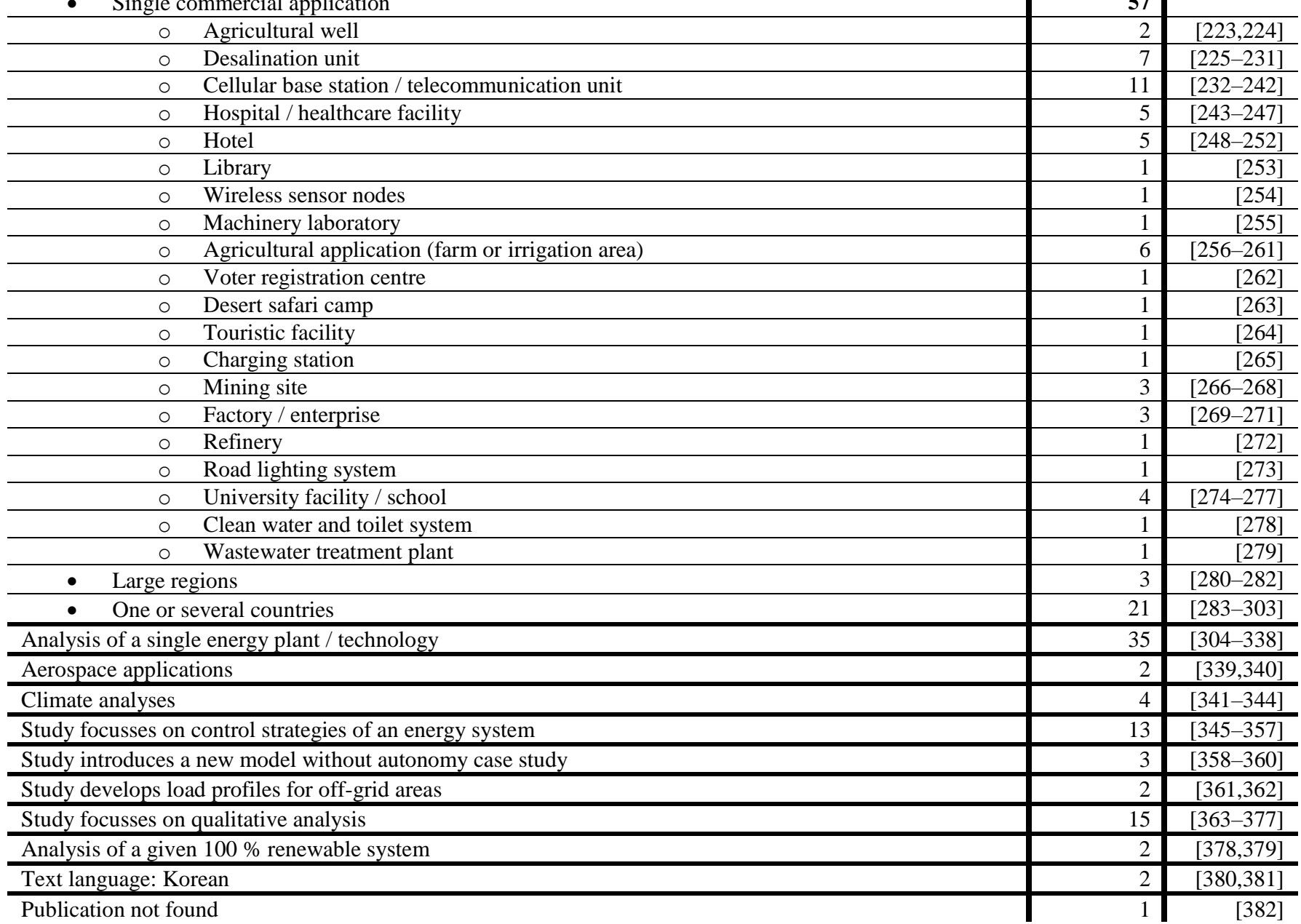

Publication not found

Table 3: Distribution of the studies among the journals in which they were published. Only those journals are shown which have published five or more studies.

\begin{tabular}{l|r|r} 
Journal & Number of studies & Share in 123 studies [\%] \\
\hline Energy & 16 & 13 \\
\hline Renewable Energy & 14 & 12 \\
\hline Energy Conversion and Management & 9 & 7 \\
\hline International Journal of Renewable Energy Research & 9 & 7 \\
\hline Applied Energy & 7 & 6 \\
\hline Energies & 7 & 6 \\
\hline Journal of Cleaner Production & 6 & 5 \\
\hline Solar Energy & 5 & 4
\end{tabular}




\begin{tabular}{l|l|c|c} 
Article & Title & Journal & $\begin{array}{l}\text { Global } \\
\text { citations }\end{array}$ \\
\hline Ashok 2007 [34] & Optimised model for community-based hybrid energy system. & Renewable Energy & 295 \\
\hline Ma et al. 2014 [134] & $\begin{array}{l}\text { A feasibility study of a stand-alone hybrid solar-wind-battery system } \\
\text { for a remote island. }\end{array}$ & Applied Energy & 257 \\
\hline $\begin{array}{l}\text { Kanase-Patil et al. 2010 } \\
\text { [73] }\end{array}$ & $\begin{array}{l}\text { Integrated renewable energy systems for off grid rural electrification } \\
\text { of remote area. }\end{array}$ & Renewable Energy & 187 \\
\hline $\begin{array}{l}\text { Østergaard and Lund 2011 } \\
\text { [101] }\end{array}$ & $\begin{array}{l}\text { A renewable energy system in Frederikshavn using low-temperature } \\
\text { geothermal energy for district heating. }\end{array}$ & Applied Energy & 180 \\
\hline Ma et al. 2014 [86] & $\begin{array}{l}\text { Technical feasibility study on a standalone hybrid solar-wind system } \\
\text { with pumped hydro storage for a remote island in Hong Kong. }\end{array}$ & Renewable Energy & 158 \\
\hline $\begin{array}{l}\text { Maleki and Askarzadeh } \\
\text { 2014 [89] }\end{array}$ & $\begin{array}{l}\text { Optimal sizing of a PV/wind/diesel system with battery storage for } \\
\text { electrification to an off-grid remote region: A case study of } \\
\text { Rafsanjan, Iran. }\end{array}$ & $\begin{array}{l}\text { Sustainable Energy } \\
\text { Technologies and } \\
\text { Assessments }\end{array}$ & 102 \\
\hline $\begin{array}{l}\text { Haghighat Mamaghani et } \\
\text { al. 2016 [61] }\end{array}$ & $\begin{array}{l}\text { Techno-economic feasibility of photovoltaic, wind, diesel and hybrid } \\
\text { electrification systems for off-grid rural electrification in Colombia. }\end{array}$ & Renewable Energy & 95 \\
\hline Gupta et al. 2010 [59] & $\begin{array}{l}\text { Steady-state modelling of hybrid energy system for off grid } \\
\text { electrification of cluster of villages. }\end{array}$ & Renewable Energy & 92 \\
\hline $\begin{array}{l}\text { Rohani and Nour 2014 } \\
\text { [112] }\end{array}$ & $\begin{array}{l}\text { Techno-economical analysis of stand-alone hybrid renewable power } \\
\text { system for Ras Musherib in United Arab Emirates. }\end{array}$ & Energy \\
\hline $\begin{array}{l}\text { Askarzadeh and dos } \\
\text { Santos Coelho 2015 [37] }\end{array}$ & $\begin{array}{l}\text { A novel framework for optimization of a grid independent hybrid } \\
\text { renewable energy system: A case study of Iran. }\end{array}$ & Solar Energy & 89 \\
\hline
\end{tabular}

\section{口Initial Search $\quad$ Adjusted Search}

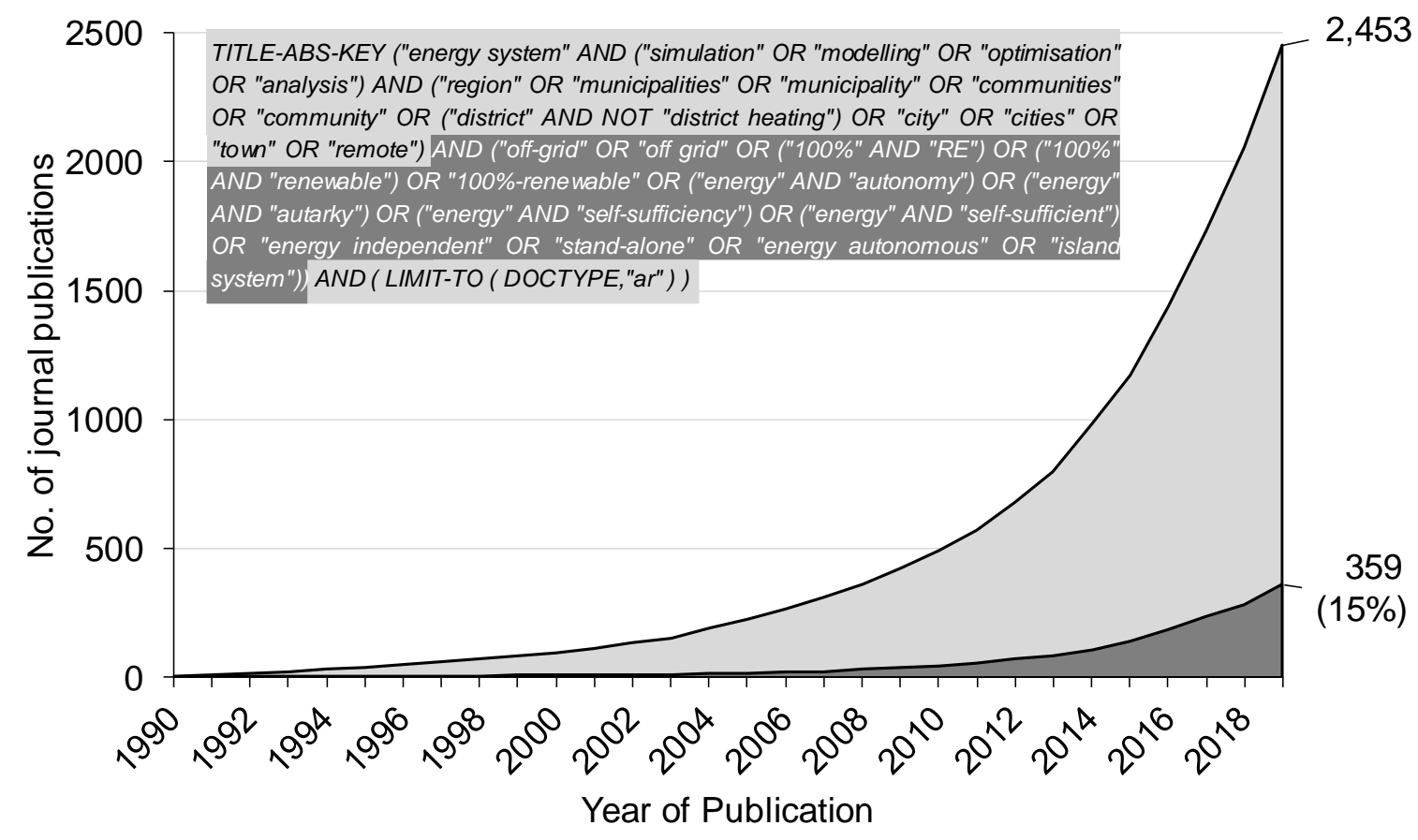

Figure 1: Development of the number of journal publications for two search queries in Scopus. The bright curve contains the publications on energy system analyses at the local level. For the dark curve, the search query has been adjusted so that the studies also deal with autonomous energy systems. The last search in Scopus was performed on November 20, 2019.

\section{Results of the literature review}

This section presents and discusses the main findings of the analysis of the 123 studies. First, section 4.1 explains the methods and models used in the studies. Subsequently, section 4.2 shows the system boundaries, i.e. which spatial resolution and which types of demand and consumption sectors are considered. The type and feasibility of energy autonomy under consideration is presented in section 4.3. In the following section 4.4, the temporal resolution is discussed. Section 4.5 then indicates the included technologies before section 4.6 examines the 
consideration of grid infrastructures. Finally, section 4.7 compares and discusses the costs for local energy autonomy resulting in the studies.

The supplementary Microsoft Excel file in the online appendix contains all the information discussed in this article. Not all aspects could be identified in all studies. In some of these cases, the information in the online table are given in parentheses, which indicates assumptions based on detailed analysis of the study. If, in the following sections, the shares in the number of studies do not add up to 123 or the percentages do not add up to 100\%, this is due to the fact that not all information could be retrieved from every study.

\subsection{Methodologies and models}

The methods employed in the reviewed literature (cf. Table 5) range from simple energy balancing calculations (e. g. $[71,100,105])$ to simulations (e. g. [80,95,103]), metaheuristics (e. g. genetic algorithm [70], discrete harmony search [89], artificial bee swarm optimization [90,91] or flower pollination algorithm [114]), mixedinteger linear optimizations (e. g. [31]) and multi-objective optimizations (e. g. [113]).

Table 5: Overview of the general methodologies applied in the studies.

\begin{tabular}{|c|c|c|}
\hline General methods & Study & Number of studies \\
\hline Artificial bee swarm optimization & {$[90,91]$} & 2 \\
\hline Biography based optimization algorithm & {$[133]$} & 1 \\
\hline Chaotic search & {$[128,129]$} & 2 \\
\hline Cukoo search & [116] & 1 \\
\hline Discrete harmony search & {$[48,89,128]$} & 3 \\
\hline Electricity System Cascading Analysis & {$[65]$} & 1 \\
\hline Energy balancing calculation & {$[71,100,105,123]$} & 4 \\
\hline Firefly algorithm & {$[115]$} & 1 \\
\hline Flower Pollination algorithm & [114] & 1 \\
\hline Fuzzy analytic hierarchy process & [99] & 1 \\
\hline Genetic algorithm & {$[70,107]$} & 2 \\
\hline Grey relation analysis & [99] & 1 \\
\hline Life cycle cost analysis & {$[88]$} & 1 \\
\hline Multi-objective particle swarm optimization & {$[38,125,126]$} & 3 \\
\hline Multi-objective crow search algorithm & [69] & 1 \\
\hline Multi-objective optimization & [113] & 1 \\
\hline Non-dominated sorting genetic algorithm-II & {$[125,126]$} & 2 \\
\hline Optimization & {$[8,31,35,50,55,57,59,60,64,73,75,79,93,99,110,118,146]$} & 16 \\
\hline Multi-criteria-decision analysis (MCDA) & {$[81,93]$} & 2 \\
\hline Particle swarm optimization & {$[37,62,102]$} & 3 \\
\hline Simulated annealing & [128] & 1 \\
\hline Simulation & $\begin{array}{r}{[25-30,32-34,36,39-44,46,47,49,51-54,56,58,61,63,66-} \\
68,72,76-78,80-87,92,94- \\
98,101,103,104,106,108,109,111,112,117,119- \\
122,124,127,130-132,134-145]\end{array}$ & 69 \\
\hline
\end{tabular}


When investigating the methods, it is striking that in most cases only simplified calculations are carried out. For example, the number and size of plants is usually predefined and not optimized. Simulations are frequently used (56\%, cf. Table 5) and often referred to as optimization. The best examples are the simulation softwares HOMER and EnergyPLAN, which are used in 61 (50\%) and 7 (6\%) studies respectively (cf. Table 6). Apart from HOMER and EnergyPLAN, other models appear only once or twice or are not specified in the studies (cf. Table 6).

Although most HOMER studies call it optimization, in its core HOMER is a simulation model [383]. First, plant types and capacities as well as load demand profiles and renewable potentials are specified. Then the simulation is used to balance energy generation and consumption and calculate the costs. Thousands of scenarios with different parameters can be simulated in a sensitivity analysis. Subsequently, in the so-called optimization, the best solution is selected from among all scenarios depending on the selected criterion (e.g. minimization of costs or fuel usage) [383]. This explorative approach to identifying a pareto front does not necessarily yield the optimal solution. The vast majority of the studies reviewed here in which HOMER is used have a similar structure: First, the economic parameters, the load profile as well as the renewable potentials and the energy system under consideration are described for a particular application. The best energy system is then usually selected on the basis of costs (97\% of cases). These studies therefore typically focus on case studies rather than methodological innovations. The aim of these studies is usually to reduce the diesel consumption of a remote off-grid area. In three studies, newly developed methods were compared with the HOMER model. The results showed that a Biogeography Based Optimization (BBO) algorithm [133], a Genetic Algorithm [70] or the so-called LINGO model [73] perform better than the HOMER model in terms of computing time and minimization of costs. The BBO algroithm, for example, found a better solution than HOMER and reduced the computing time from $15 \mathrm{~h}$ to $0.7 \mathrm{~h}[133]$.

Table 6: Models used in the analysed literature.

\begin{tabular}{|c|c|c|}
\hline Model & Study & Number of studies \\
\hline $\begin{array}{l}\text { HOMER or HOMER } \\
\text { Pro }\end{array}$ & $\begin{array}{r}{[25-30,33,36,39,40,42-44,46,47,49,51,54,56,58,61,63,66,67,72,76-78,81-} \\
84,87,92,94,96-98,106,108,109,111,112,119-122,127,131,132,134- \\
142,144,145]\end{array}$ & 61 \\
\hline EnergyPLAN & {$[45,52,53,101,117,124,130]$} & 7 \\
\hline $\mathrm{RE}^{3} \mathrm{ASON}$ & {$[8,93]$} & 2 \\
\hline BeWhere / Phasma & [118] & 1 \\
\hline FINE / TSAM & [146] & 1 \\
\hline FlexiGIS & [31] & 1 \\
\hline $\mathrm{H}_{2} \mathrm{RES}$ & [80] & 1 \\
\hline IREOM & [74] & 1 \\
\hline ISLA & [99] & 1 \\
\hline LINGO v.10 & [73] & 1 \\
\hline OSeMOSYS & [57] & 1 \\
\hline $\mathrm{P}^{2}$ IONEER & [79] & 1 \\
\hline RegFin & {$[105]$} & 1 \\
\hline
\end{tabular}

Despite the weaknesses that HOMER shows in determining an optimal energy system, the advantages of the tool should also be appreciated. It is an open access tool that can be used by everyone and does not require a lot of 
computing power. Therefore, the model is particularly useful for studies on remote areas in countries with low or middle income (75\% of the HOMER studies reviewed here) according to the country classification of the World Bank [384] (cf. Table 8).

In contrast to the HOMER model, the EnergyPLAN model was only used for case studies in countries with middle (China [130]) or high (Italy [45], Croatia [52,117], Denmark [53,101], Ireland [124]) income. However, this model is also classified "as a simulation tool rather than an optimisation tool" [385] and only includes a dispatch optimisation. This means that the user has to specify the technologies and thus has to have a comprehensive understanding of energy system analysis (as in HOMER). A step in the right direction was the introduction of Homer Pro, which is intended to simplify the use of the HOMER software for inexperienced users [386].

Beyond these two models, there are more and more model approaches that generate inputs for optimization models on the basis of publicly available data such as OpenStreetMap². Examples in the reviewed literature are the FlexiGIS model [31] and the RE ${ }^{3}$ ASON model $[8,93]$. At least for FlexiGIS an open-source publication in GitHub is planned, according to the authors [31]. These models would enable inexperienced users in the field of energy system analysis to determine the energy potentials of a region and optimize the energy system. Neither potentials nor technologies and plant sizes would have to be determined before application of the models.

\subsubsection{Perspective}

In most energy system analyses, a central planner was used as the perspective. Only in Ramchandran et al. [108], the perspective of a Renewable Energy Service Company was taken instead. On the one hand, these central planner approaches show the macroeconomic optimum. On the other hand, however, these approaches often fall short of realisation: it could be difficult to convince individual homeowners to install the technologies in their homes that are optimal from a macroeconomic but not a business point of view. Therefore, studies of possible incentive systems that could encourage homeowners to implement the macroeconomic energy autonomy plan are required. First conclusions could be drawn by comparing the optimal energy system at building level from the perspective of the building owner on the one hand and from the macroeconomic perspective on the other.

Promising approaches include for example the combination of optimization approaches with multi-criteriadecision analysis (MCDA), as in [81] and [93]. These types of analyses do not yet include the perspective of every inhabitant, but at least the perspective of their most important representatives. This could help to strengthen the feasibility of an energy autonomy plan.

\subsubsection{Target criterion}

The adopted perspective is closely linked to a further shortcoming of many of the studies examined: the choice of the target criterion. In 103 (84\%) of the studies only costs were minimized. As already shown in section 1, however, costs are not the only reason for energy autonomy projects. In a few studies, a different target criterion than costs is applied, but these analyses do not represent an improvement since also only one criterion is considered: technical feasibility [86,117], annual efficiency [103,104] or coal consumption [130]. However, beside the above-mentioned

2 https://www.openstreetmap.org/ 
MCDA approaches, other multi-objective approaches represent improvements. In addition to costs, the criteria in Table 7 are also taken into account in the reviewed studies. Possible weightings for the criteria could either be determined on site before the case studies, or taken from surveys such as in [5].

Table 7: Applied target criteria besides cost in the studies with MCDA or multi-objective optimizations.

\begin{tabular}{|c|c|c|}
\hline Criterion & Study & Number of studies \\
\hline $\mathrm{CO}_{2}$ emissions & {$[71,81,93,99,113]$} & 5 \\
\hline Land use & {$[55,71,81,84]$} & 4 \\
\hline Security of supply & {$[38,69,84,99]$} & 4 \\
\hline Forecast accuracy & {$[125,126]$} & 2 \\
\hline Renewable share in energy supply & {$[38,84]$} & 2 \\
\hline Social acceptance & {$[81,99]$} & 2 \\
\hline Community net imports & [93] & 1 \\
\hline Creation of jobs & [81] & 1 \\
\hline Ease of installation and operation & [99] & 1 \\
\hline Flexibility of the system for future expansion & [99] & 1 \\
\hline Gross domestic production & [105] & 1 \\
\hline Health issues & [81] & 1 \\
\hline Human development index & [81] & 1 \\
\hline Noise & [81] & 1 \\
\hline Risk of flash floods & [81] & 1 \\
\hline Technical efficiency & [81] & 1 \\
\hline Technical reliability & [81] & 1 \\
\hline Technical lifespan & [81] & 1 \\
\hline Technical scalability & [81] & 1 \\
\hline Technical maturity & [81] & 1 \\
\hline Universal education and gender equality & [81] & 1 \\
\hline Water consumption & [55] & 1 \\
\hline Water quality & [81] & 1 \\
\hline
\end{tabular}

\subsection{System boundaries}

This section first persents the spatial resolution and location of the case studies in the reviewed literature (cf. section 4.2.1). Section 4.2.2 then shows that the focus is primarily on the demand product electricity. Finally, the demand sectors considered in the studies are highlighted (cf. section 4.2.3).

\subsubsection{Spatial resolution and location}

Table 8 classifies the case studies of the reviewed papers according to the income classification of The World Bank [384]. Most of the studies were conducted in the lower middle income country (LMIC) India (21), upper middle income countries (UMIC) Iran (17) and China (6) as well as the high income country (HIC) Germany (7). Whilst the case studies in India and Iran focused mainly on the energy systems of remote areas without grid connection, in Germany a complete electrification already exists. The case studies on complete autonomous energy systems in high income countries are therefore more about isolating communities from the transmission grid. These studies are linked to the question whether the energy system transformation should be achieved through decentralised or 
centralised expansion of renewable energy sources. In [387], for example, the decentralised expansion is evaluated as more cost-effective for the German case due to higher required transmission grid expansion costs in the centralised case. The possible impacts of autonomous communities on the surrounding energy system (cf. section 4.3) therefore plays a very important role especially in the HIC studies.

Whilst the low income countries (LIC), the LMIC and the UMIC mainly consider remote rural areas as case studies with $100 \%, 92 \%$ and $74 \%$ of the studies, respectively, these remote areas account for only $23 \%$ of the studies on HIC. Instead, studies on HIC also often investigate energy autonomy for islands (23\%), cities (20\%), regions (17\%) and municipalities (14\%). This is also reflected by the number of residents examined in the case studies: in the studies on LIC, LMIC and UMIC case studies with a maximum of 4,750 inhabitants are analysed; in the HIC studies, case studies with up to 640,000 inhabitants are investigated. The exact area or city names of the case studies as well as the number of households and inhabitants examined can be found in the supplementary Excel file.

In this context, it is noticeable that the complexity of the applied methodology adapts to the size of the considered region. This means, the smaller a region is chosen, the more details can be included in the analysis. For example, in Waenn et al. [124] the operation of the energy system with 640,000 inhabitants is determined with the help of a less complex simulation (EnergyPLAN). The largest case study in which an energy system is designed with the help of an optimization is in Schmidt et al. [118]: a large region with 21,000 inhabitants. However, in Schmidt et al. only two time slices are considered during the optimization (cf. section 4.4.2) to reduce the model complexity. In $[8,61,77,105,107,112,144]$ different spatial scales were compared as case studies, i.e. the number of households or inhabitants was varied. However, these studies do not yet provide indications about the optimal size of energy autonomous energy systems. 
Table 8: Classification of the countries according to The World Bank [384], in which the case studies are conducted in the reviewed literature as well as the share in the total of 123 publications. This country classification is based on the gross national income per capita [387].

\begin{tabular}{|c|c|c|c|}
\hline $\begin{array}{l}\text { Income } \\
\text { group [384] }\end{array}$ & $\begin{array}{l}\text { Gross national income } \\
\text { per capita }[384][\$]\end{array}$ & Countries and studies & $\begin{array}{l}\text { Share } \\
{[\%]}\end{array}$ \\
\hline Low income & {$[0 ; 1,025)$} & Ethiopia [67,97], Rwanda [144], Tanzania [140], Yemen [32] & 4 \\
\hline $\begin{array}{l}\text { Lower } \\
\text { middle } \\
\text { income }\end{array}$ & $(1,025 ; 3,995]$ & $\begin{array}{l}\text { Bangladesh [51,92,136], Cameroon [96,127], Egypt [114], Ghana [27,29], India } \\
\text { [30,34,46-48,59,60,73,74,78,82,88,94,102,107,108,110,115,116,131,133], } \\
\text { Indonesia [33,121], Nigeria [28,137,139], Pakistan [72,76,111], Philippines [99], } \\
\text { Timor-Leste [57] }\end{array}$ & 33 \\
\hline $\begin{array}{l}\text { Upper } \\
\text { middle } \\
\text { income }\end{array}$ & $(3,995 ; 12,375]$ & $\begin{array}{l}\text { Algeria [44,135], Brazil [119], China [70,81,83-85,130], Colombia [61], Cuba } \\
\text { [132], Iran [26,35-37,42,62,64,66,69,89-91,125,126,128,129,141], Iraq [138], } \\
\text { Malaysia [63,65,120,122], Maldives [56], Mexico [55], Turkey [54] }\end{array}$ & 30 \\
\hline High income & $(12,375 ;$ inf $)$ & $\begin{array}{l}\text { Australia [41,58], Austria [118], Canada [39,40,106,123,145], Croatia } \\
\text { [52,80,117], Denmark [53,101], Finland [105], Germany [8,31,71,79,93,95,146], } \\
\text { Greece [103,104], Hong Kong [86,87,134], Ireland [124], Italy [45], Japan [143], } \\
\text { Korea [77], Oman [25], Saudi Arabia [43,109,142], Scotland [49], Sweden [38], } \\
\text { Switzerland [113], United Arab Emirates [98,112], USA (Alaska) [50] }\end{array}$ & 33 \\
\hline
\end{tabular}

\subsubsection{Demand}

In all the studies reviewed, the electricity demand of the energy system is included. Heating or cooling demand, on the other hand, is only considered in $30(24 \%)$ or $13(11 \%)$ of the studies, respectively. As already indicated in section 1 for energy autonomy projects, this also demonstrates the focus on electricity in the literature. In most cases, the demand is based on time series that have been determined or collected beforehand. However, there are also examples of energy autonomy case studies such as [8,31,93], in which the demand and load profiles are determined automatically on the basis of publicly available data. The electricity and heat generation technologies used in the studies are presented in section 4.5.

In addition to electricity and heat, other demand products such as food are also indirectly taken into account, for example through land-use competition as in Schmidt et al. [118]. However, only direct demand products are discussed in the present literature review. This includes the demand for water considered in ten studies. In $[29,47,48,64,94]$ this is considered by the electricity demand of a water pump, e. g. for an agricultural well. In $[68,75,80,90]$ the energy system contains a desalination unit for water distillation. In Fuentes-Cortés et al. [55] the water-energy nexus is considered in the analysis, which means that water demand in the energy supply is taken into account. In this case the water demand includes fresh water for households, water used for regulating the temperature of the thermal demand as well as water needed as by-product in the combined heat-and-power (CHP) units. Water consumption is included in [55] alongside costs and land use in the multi-objective function of the optimization model. Therefore, [55] in particular shows a suitable way to consider water demand in future studies about autonomy. The studies $[48,55,75,80]$ are the only examples which consider all three types of demand (electricity, heat and water). 


\subsubsection{Consumption sectors}

Among the consumption sectors, mainly the residential sector is considered (102 studies; 83\%), followed by the commercial sector $(55 ; 45 \%)$, industrial sector $(23 ; 19 \%)$ and transportation sector $(11 ; 9 \%)$. The energy system is usually designed for all considered sectors. By contrast, in Bagheri et al. [39] the residential, commercial and industrial sectors are examined in separate analyses. Thereby, the energy system for the industrial sector shows the lowest levelized cost of electricity (LCOE) in the autonomous case with $100 \%$ renewable energies. Whilst the commercial sector with schools and hospitals also is important in studies about remote areas, larger industries and the transport sector are considered almost exclusively in case studies for municipalities, cities, islands or larger regions. In [73,74], industries are also considered in remote villages. However, they are referred to as rural industries, which probably corresponds more to the commercial sector of HIC in terms of demand structure. An interesting point is that in the cases where heat and industry were regarded, only a balanced autonomy is part of the analysis. This is probably due to the fact that, for example, high-temperature heat in industry can only be generated with specific renewable energy plants and, in the completely autonomous case, would be associated with excessively high costs.

For residential, commercial and industrial sectors, the demand is usually known in advance in the studies. However, for the consideration of the transport sector several different approaches are applied. In [71,101,105,124] a fixed fuel demand for traditional vehicles is covered. In [52,53,117], electric vehicles (EVs) are considered within the EnergyPLAN model. In Dorotić et al. [52] all vehicles and ferries on the island of Korčula in Croatia are replaced by electrically powered alternatives. The EVs not only serve as batteries, but can also be used for vehicleto-grid, i.e. feeding electricity from the EV battery into the grid. Šare et al. [117] analyse three scenarios for the municipality Dubrovnik in Croatia with different EV penetrations in 2020, 2030 and 2050. Krajačić et al. [80] and Oldenbroek et al. [100], on the other hand, included fuel cell vehicles in their energy system analyses. In some scenarios in [80] the transport load is covered $100 \%$ by renewable hydrogen. None of the studies optimizes the number of electric or fuel cell vehicles.

\subsection{Feasibility and type of autonomy}

In the reviewed literature, studies on completely autonomous energy systems predominate with 110 (89\%), whereas balanced local energy autonomy is only considered in $14(11 \%)$ studies. The only study that analyses both cases seems to be Sameti and Haghighat [113], in which a net-zero energy district is investigated in three scenarios with grid connection and one as a stand-alone variant without grid connection.

Generally energy autonomy is feasible in the case studies. The only exception is the study by Alhamwi et al. [31] who do not obtain a feasible solution in their energy system model and come to the conclusion that an off-grid city $(165,000$ inhabitants) is economically and technically not practicable. However, there are also other examples which do not come to a favourable result for local energy autonomy. Krajačić et al. [80] find that the cost of electricity for a $100 \%$ renewable island is up to 15 times higher than the current (2009) electricity price. Furthermore, in Oldenbroek et al. [100] a 100\% renewable supply can only be achieved if $20 \%$ of the vehicle fleet are fuel cell vehicles. Also Šare et al. [117] come to the conclusion that large storage capacities are necessary for a $100 \%$ renewable supply. Jenssen et al. [71] show that the available biomass potentials of a model municipality 
are sufficient for $100 \%$ power and heat supply, but not to replace transport fuel. All these examples have in common that they examine bigger regions, cities and islands as case studies in high-income countries in Europe.

In the studies on completely autonomous energy systems, uncertainties due to disconnection from the grid infrastructures should play a very important role, since a non-optimal design of the energy system cannot be compensated by imports. Therefore it is even more important to design these energy systems robustly. There are several appropriate approaches in the studies. For example, in 39 (32\%) studies a possible security of supply below $100 \%$ is implemented as a loss of power supply probability (LPSP). In most cases ([35$37,46,48,59,60,64,66,70,72-74,82,83,85,86,90-92,96-98,102,110,114,115,127,129])$, the LPSP is modelled as a fixed value or results from other fixed values. Other studies $([38,62,69,84,99,107,116])$ in which the LPSP is associated with weightings or penalty costs and thus integrated into the objective function of an optimization represent an improvement. In Hakimi et al. [62] different penalty costs were assumed for the residential, commercial and industrial sector. In future studies, the so-called value of loss load could be a suitable estimation of penalty costs. In Shivakumar et al. [388], for example, the value of loss load was calculated for households in all European Union member states. This data set with penalty costs based on the same methodology could make results of studies more comparable. As expected, the LPSP are rarely considered in high income countries, as the inhabitants are accustomed to high security of supply. Four case studies in Canada [145], Sweden [38] and Hong Kong $[86,134]$ are the only examples. However, for autonomous systems these LPSP become more relevant.

Further studies try to robustly design off-grid energy systems by taking extreme conditions into account. In Petrakopoulou et al. [103,104], the plants of the energy system are over-dimensioned and complementary technologies are used. In addition, the optimization model in Weinand et al. [8] considers extreme days on which demand is particularly high and no wind or solar radiation is present.

\subsection{Time structure and pathway}

In this section the time horizon (section 4.4.1), the chosen temporal resolution (section 4.4.2) and the pathway for the energy system transition (section 4.4.3) are demonstrated.

\subsubsection{Time horizon}

The time horizon in the case studies is usually chosen between 15 and 25 years, which represents an appropriate choice for estimating total discounted system costs or LCOEs for an energy system. However, there are also variations upwards and downwards: Adamarola et el. [29] and Drydale et al. [53] even consider 35 and 45 years respectively. Jenssen et al. [71], Moeller et al. [95], Oldenbrock et al. [100], Østergaard and Lund [101] as well as Šare et al. [117] consider one year whereas Kandil et al. [75] use only a time horizon of 24 hours. For the latter study, a time horizon of 24 hours could be too short, even though only the operating costs of an autonomous energy system are determined. At least an extreme day should have been considered for this analysis.

\subsubsection{Time resolution}

The time resolution of models is of particular importance in studies on energy autonomy. This is especially true for completely autonomous energy systems (cf. section 4.3). Non-optimal design of balanced energy autonomous 
systems could be compensated by imports from surrounding energy infrastructures. This does not apply for complete autonomy. Therefore, a particularly critical assessment is made when off-grid energy systems are designed on the basis of an annual energy balance, as it seems in Stephen et al. [123]. Stephen et al. [123] investigate the residential and commercial energy supply for an off-grid Canadian aboriginal community. There are also other examples with a very rough time resolution, but these studies only consider balanced autonomy: Jenssen et al. [71] and Peura et al. [105] also conduct an annual balancing of energy (i.e. one time step) whereas the optimization model of Schmidt et al. [118] is based on two seasons (winter/summer) per year (i.e. two time steps).

In almost all studies $(91,74 \%)$ the time resolution is set to hours. There is only one study with a higher time resolution, namely Kötter et al. [79] with 15-minute time steps. Kötter et al. investigate the balanced energy autonomy of a region consisting of 17 sub-regions in Germany. However, it is not clear how many of the 15minute time steps are used in the analysis. The robustness of results on completely autonomous energy systems based on models with hourly resolution must at least be questioned. In these cases it is even more important to consider the methods explained in the previous section, such as LPSP or extreme conditions. In addition, energy systems based on base-load capable technologies such as biomass can be considered more robust than those based only on volatile energy such as wind or photovoltaics (PV) (more on this in section 4.5). Usually all hours of a year are considered in the investigations with hourly resolution (59 of 91, 65\%).

Overall it seems, however, that the number of time steps decreases with the complexity of a model, presumably in order to avoid computing time problems: the RE ${ }^{3} \mathrm{ASON}$ model based on public data uses only 288 [93] or 432 [8] time slices and the multi-objective optimizations of Fuentes-Cortés and Ponce-Ortega [55] or Yazdanpanah Jahromi et al. [125] use only 96 and 744 time slices respectively. Another example is the optimization with multitier targets (e. g. scenarios with different demands) according to the World Bank Global Tracking Framework by Fuso Nerini et al. [57], which comprises only 18 time steps per year. This is a general problem of energy system analyses. However, as mentioned above, the number of time steps is more crucial in energy system analyses including complete energy autonomy.

\subsubsection{Pathway}

Energy autonomy projects are always associated with the objective that the energy system will become energy autonomous in the medium to long-term future. This means that there will be a transition over several years. However, in almost all reviewed studies $(115,94 \%)$, overnight is chosen as the pathway, i.e. the new energy system replaces the old one immidiateley and not during several years. This would correspond to an inaccurate calculation of total discounted system costs or LCOEs, as demands and costs may change during the considered time horizon. Only in Dorotić et al. [52], Drysdale et al. [53], Fuso Nerini et al. [57], Krajačić et al. [80], McKenna et al. [93] and Weinand et al. [8] was the pathway modeled as a transition. Dorotić et al. [52] seem to simulate at least every second year in EnergyPLAN from 2011 to 2030. The $\mathrm{CO}_{2}$ emissions of the system are decreasing and the renewable energies share is increasing until they reach their minimum $\left(0 \% \mathrm{CO}_{2}\right.$ emissions) or maximum (100\% renewable energies share) values in 2030. Drysdale et al. [53] also use the EnergyPLAN model. However, they seem to simulate only two years, 2016 and 2050. Fuso Nerini et al. [57] apply the system optimization model 
OSEMOSYS for a case study village in Timor Leste. The authors seem to optimize every year from 2010 until 2030. However, as mentioned above, for each year only 18 time steps are considered (six per day and three seasons per year), i.e. 360 time steps in total. Thereby the demand changes during the time horizon. For example, it is assumed, that the households reach the target tier in 2025. The target tier would be one of five tiers: for example the households would get access to general lighting, air circulation and television in tier-2 or small appliances in tier-3. In the $\mathrm{H}_{2} \mathrm{RES}$ model in Krajačić et al. [80] every fifth year from 2005 until 2015 is simulated. The same applies to the RE³ASON model in McKenna et al. [93] and Weinand et al. [8] (time horizon from 2015 until 2030). In the two latter studies, however, the method is a mixed-integer linear optimization: all four years are optimized simultaneously, i.e. it is decided when which plant or measure will be installed. By considering the existing infrastructure (e.g. already installed PV modules), as in the RE ${ }^{3} \mathrm{ASON}$ model, models are enabled to consider a transition pathway.

\subsection{Technologies}

As already discussed in section 4.1, many case studies on energy autonomous remote rural areas deal with the reduction of diesel and the increase of renewable energies in the system. As shown in Table 9, diesel, therefore, is the most frequently considered in the studies after PV, wind and stationary batteries. A total of 73 studies (59\%) consider conventional generation technologies such as diesel generators and gas fired CHP / turbine plants in their energy system analyses.

When classifying biomass CHP, hydropower plants, deep geothermal plants as well as conventional generation technologies as baseload-capable, 26 studies (21\%) remain, in which only volatile generation technologies are considered. In 16 of these 26 studies, no long-term storage options such as hydrogen storage, pumped-hydrostorage or power-to-gas are considered. In such cases, it is essential to take account of uncertainties. In ten of the 16 studies [35-37,66,70,85,91,115,116,134], these uncertainties are at least addressed via LPSP and in another study [103] by including extreme conditions. Even more than in other studies, the results of the completely autonomous energy systems in Al-Shetwi et al. [32], Khan et al. [76], Kim et al. [77] and Mas'ud [137] must therefore be questioned, in which only volatile energy technologies and no uncertainties are considered.

The fact that so few studies examine heating or cooling technologies (cf. Table 9) is related to the focus on electricity in the studies (cf. section 4.2.2). In addition, technologies that do not belong to the standard technologies such as PV or wind are primarily investigated in case studies in HIC in Europe. For example, the technologies deep geothermal energy, power-to-gas or district heating are analysed primarily in Germany (deep geothermal energy: [8]; power-to-gas: [79,95]; district heating: [8,71] ) or Denmark (deep geothermal energy (only heat): [101]; district heating: [53,101]), while unconventional vehicles such as EVs [52,53,117] or fuel cell vehicles $[80,100,141]$ are examined primarily in case studies in Croatia. This suggests that the studies on remote rural areas are primarily concerned with the electrification of the area and not with the choice of optimal energy technologies. On the other hand, technologies such as deep geothermal energy (despite high potential in e.g. India or SubSaharan Africa [389]) are not relevant for these rather small regions (see section 4.2.1) due to high fixed costs [8]. 


\begin{tabular}{l|l|r}
\multirow{2}{*}{$\begin{array}{l}\text { Category } \\
\text { Renewable } \\
\text { electricity } \\
\text { generation } \\
\text { technologies }\end{array}$} & Technology & No. of studies \\
\cline { 2 - 3 } & Wind (onshore) & $117(95 \%)$ \\
\cline { 2 - 3 } & Biomass CHP & $85(69 \%)$ \\
\cline { 2 - 3 } & Hydropower plant & $39(32 \%)$ \\
\cline { 2 - 3 } & Concentrated solar power & $21(17 \%)$ \\
\cline { 2 - 3 } & Deep geothermal plant & $3(2 \%)$ \\
\hline \multirow{2}{*}{$\begin{array}{l}\text { Heating } \\
\text { cooling } \\
\text { technologies }\end{array}$} & District heating / cooling & $2(2 \%)$ \\
\cline { 2 - 3 } & Heat pump & $10(8 \%)$ \\
\cline { 2 - 3 } & Solar thermal collector & $7(8 \%)$ \\
\cline { 2 - 3 } $\begin{array}{l}\text { Storage } \\
\text { technologies }\end{array}$ & Electric heater & $6(5 \%)$ \\
\cline { 2 - 3 } & Stationary battery & $6(5 \%)$ \\
\cline { 2 - 3 } & Thermal & $93(76 \%)$ \\
\cline { 2 - 3 } & Pumped-hydro & $18(11 \%)$ \\
\cline { 2 - 3 } & Power-to-Gas (methanisation) & $8(7 \%)$ \\
\hline \multirow{2}{*}{$\begin{array}{l}\text { Transport } \\
\text { technologies }\end{array}$} & Electric vehicle (modelled with battery) & $4(3 \%)$ \\
\cline { 2 - 3 } $\begin{array}{l}\text { Conventional } \\
\text { generation } \\
\text { technologies }\end{array}$ & Fuel cell vehicle & $2(2 \%)$ \\
\cline { 2 - 3 } & Diesel generator & $3(2 \%)$ \\
\cline { 2 - 3 } & Gas fired CHP & $3(2 \%)$ \\
\cline { 2 - 3 } & & $63(51 \%)$ \\
\hline
\end{tabular}

In summary, the studies on local energy autonomy investigate a wide range of technologies. However, for a robust design of an energy autonomous system based on renewable energies, the combination of fluctuating and nonfluctuating generation technologies as well as different storage technologies could be advantageous. Some of these technologies that could be beneficial in a completely autonomous case, such as seasonal heat storage, have not yet been analysed. In general, the more diverse the technologies under consideration, the more economically or environmentally sustainable the energy system could be designed. On the other hand, the complexity and computing time of energy system models increases with the number of technologies. In any case, work still needs to be done in which a very broad range of technologies is considered and the optimum technologies for energy autonomy are identified. Based on the results of the reviewed studies, no definite trend towards the most economic technologies for achieving energy autonomy can yet be identified (cf. section 4.7).

\subsection{Grid infrastructures}

Grid infrastructures are rarely modeled in the studies. Heating grids are implemented only in $[8,93,113]$, the electricity grid only in $[8,31,93,95]$. In $[27,78]$ at least the costs for setting up the distribution network are taken into account. It is interesting to note that all four case studies that consider the electricity grid are located in Germany. In $[8,93]$ the electricity and heating network is only represented in a simplified way by energy flows between districts. However, Weinand et al. [8] also contains a transferable approach for designing district heating networks in arbitrary municipalities. District heating systems are also designed in Sameti and Haghighat [113]. While in [8] the district heating network is modelled top-down for entire municipalities, [113] is better suited as a bottom-up application for districts for which exact building locations and energy demands are known. Therefore, depending on the application, the two studies offer possible approaches for future analyses.

In Moeller et al. [95], the capacities and connections of the electric transmission network between German regions are modeled. The analysis also examines whether the transmission capacities are sufficient, depending on the share of renewable energies. In the FlexiGIS model in Alhamwi et al. [31], OpenStreetMap is used to obtain data on 
lines and substations of the distribution network in order to determine the optimal placement of a battery storage in an urban area. Unfortunately, power grid data is not yet completely included in OpenStreetMap and therefore this method is not usable for every case study.

Electricity grids are only considered in a simplified way in the papers. A promising approach for future studies could be the one of Morvaj et al. [156], in which the distribution network is modelled according to a linearized AC power flow approach. Of interest is the implementation of a binary modelling variable, which determines whether the distribution grid needs to be upgraded, depending on the amount and type of renewable energies added to the energy system. In the case of an upgrade, the expansion of renewable energies would involve additional costs. However, the study uses available grid data of the IEEE European Low Voltage Test Feeder case [390]. Since this grid data is not available for arbitrary case studies, the grid capacities would have to be estimated.

\subsection{Costs}

Section 4.1 has already shown that the energy systems in the literature were mostly designed on the basis of cost minimization. Therefore, a comparison of these costs is reasonable. In 83 (68\%) of the 123 studies, the LCOEs for autonomous energy systems were stated (cf. Figure 2). For Figure 2, the LCOEs from the studies were adjusted according to inflation until 2019 [391] and converted into \$/kWh using the average exchange rates [392-394] in the year of the respective publication. As all but one of the 83 studies consider the residential sector, the household electricity price (import from grid) in the different countries is shown for comparison [395]. For eight countries (e.g. Ethiopia [67] or Yemen [32]), the household electricity price could not be found.

The mean LCOEs amount to $0.41 \$ / \mathrm{kWh}$ (black dotted line in Figure 2). Consequently, the costs in the studies of Khan et al. [76] and Hosseini et al. [66] are nearly average. The LCOEs in an energy system with 100\% renewable energy are on average $0.42 \$ / \mathrm{kWh}(0.37 \$ / \mathrm{kWh}$ without the outlier in Askari and Ameri [35]) whereas in an energy system with conventional energy 0.39 $\$ / \mathrm{kWh}(0.36 \$ / \mathrm{kWh}$ without the outlier in Shezan et al. [122]) is achieved. As expected, in studies considering both cases, the LCOEs of $100 \%$ renewable energy systems are higher than of conventional energy systems. Likewise, the LCOEs decrease if cases with security of supply below $100 \%$ are considered. Furthermore, the household electricity prices are lower than the LCOEs for the autonomous system for almost every study. The only exceptions include case studies in countries with above-average electricity prices (Australia [41], Croatia [52] and Germany [79,95]), or the two studies with the lowest LCOEs [110,113] in Figure 2.

18 out of the first 20 upward outliers in Figure 2 apply the HOMER model (for the other two, the applied model cannot be found in the article), i.e. a non-optimal design of the energy system could be responsible for the high LCOEs (cf. section 3.1). In the following, the three studies from Figure 2 with the highest upward outliers in the LCOEs are discussed (up to the study Li et al. [83] with $1.57 \$ / \mathrm{kWh}$ on average). The highest LCOEs in the study by Askari and Ameri in 2009 [35] are caused by the high inflation in Iran between 2009 and 2019 (+364\%). As a result, the costs are adjusted from originally $0.75 \$ / \mathrm{kWh}$ to $3.27 \$ / \mathrm{kWh}$. The study by Shezan et al. [122] with the high LCOEs of $2.01 \$ / \mathrm{kWh}$ needs further investigation, especially since an unmet load of $0.01 \%$ is considered here, which should reduce the LCOEs. Unfortunately, by analysing the study it is not really possible to determine 
how the HOMER model achieves the high LCOEs for the most economic energy system with PV, wind, diesel generator and stationary battery. However, surprisingly, a figure in the study shows more realistic HOMER results with LCOEs of $0.62 \$ / \mathrm{kWh}$, but these LCOEs are not discussed further in the text. In Li et al. [83] the predefined design of the energy system seems to lead to the high LCOEs of $1.54 \$ / \mathrm{kWh}$. In fact, an energy system with $500 \mathrm{~kW}$ of PV and 9.1 MWh of stationary batteries is assumed for 100 households in China. This energy system appears to be oversized, which again demonstrates the need for a good understanding of the energy system when designing energy systems with HOMER (cf. section 4.1). In addition, the PV-battery system is compared with a PV-battery-fuel cell system, but the capacities of PV and battery are not changed. Thus, it is obvious that the PVbattery system leads to lower costs.

The reason for the low LCOEs for energy autonomous systems of the downward outliers is more difficult to determine and would require an in-depth analysis in a separate study. In the case study in Rajanna and Saini [107], for example, there is great potential for baseload hydropower and bioenergy, which could be related to the low LCOEs of $0.07 \$ / \mathrm{kWh}$. Examining further studies for reasons related to LCOE would be beyond the scope of this literature review. However, the detailed table in the online appendix could be used in further studies to investigate the dependencies of the LCOEs on the characteristics of the studies, e.g. through cluster or regression analyses. The online appendix and Figure 2 are useful as a basis for evaluating future studies about local energy autonomy. If, for example, the LCOEs deviate as much from the average of $0.41 \$ / \mathrm{kWh}$ in future studies as in Li et al. [83], the applied methods and results have to be further investigated.

Since most of the studies calculate LCOEs, these figures are very suitable for comparing the results of local energy autonomy studies. However, another cost parameter that is particularly relevant for the inhabitants who have to pay for the costs of the autonomous energy system is rarely shown in the studies: total costs per inhabitant. These are only shown in Jenssen et al. [71] (1.4-2.3 k\$), Schmidt et al. [118] (220 \$/a more than in the reference scenario without autonomy) and Weinand et al. [8] $(21.0-54.8 \mathrm{k} \$)$. However, the cost per inhabitant should be included in all future studies in order to assess the feasibility of the energy autonomy project.

In some studies, the costs of the completely autonomous energy system are compared with the costs of grid connection $[34,88,98,102,112,131]$. In all examples, the grid connection scenario turns out to be less economical. This is due to the fact that these studies only consider remote areas that are far away from the nearest grid connection point. The break-even points for the distance from which the network connection would be worthwhile are calculated in $[88,102,112,131]$. This is also related to the question of the optimal degree of centralization as well as the optimal size of energy autonomous municipalities (cf. section 5). 


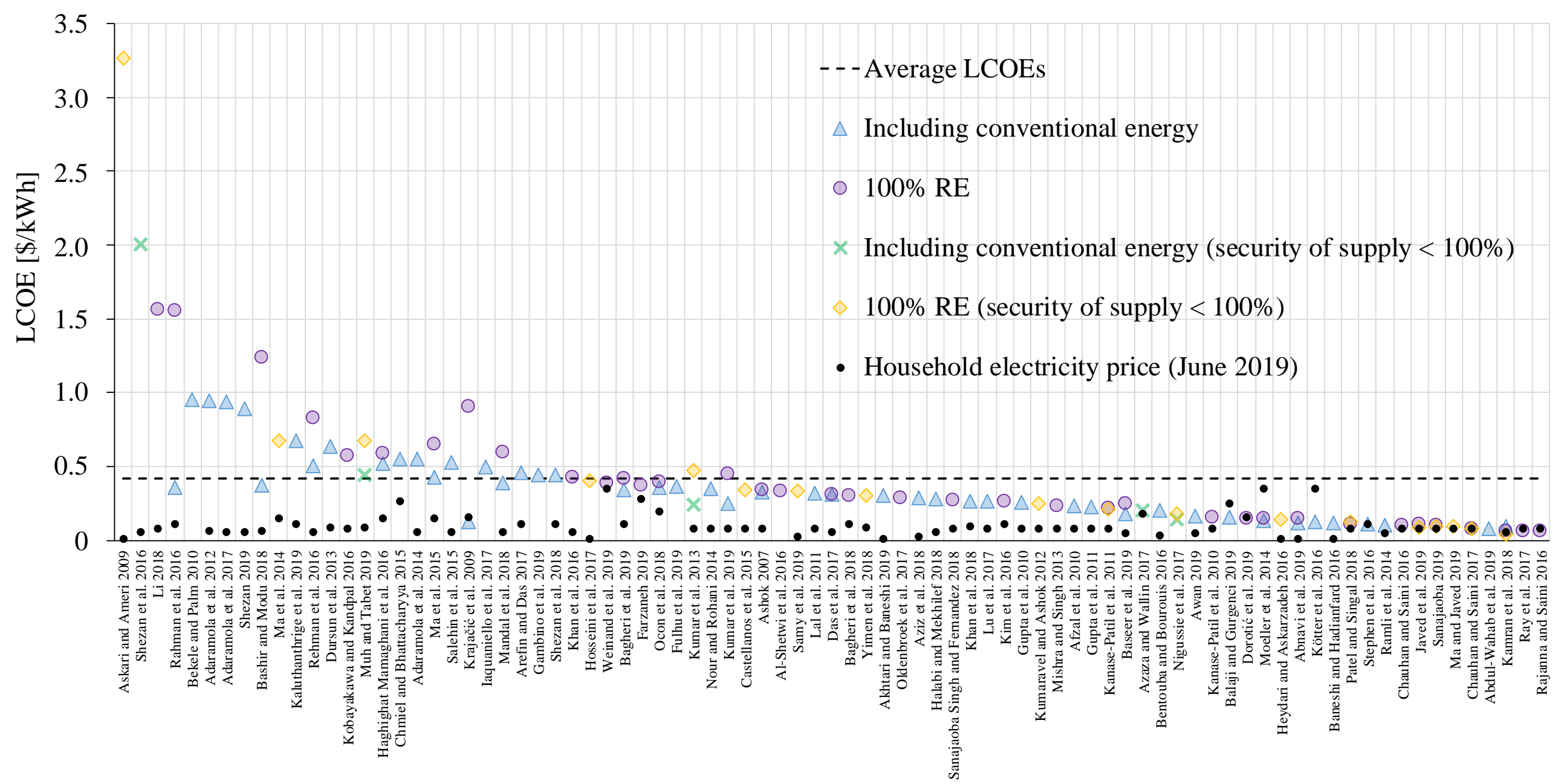

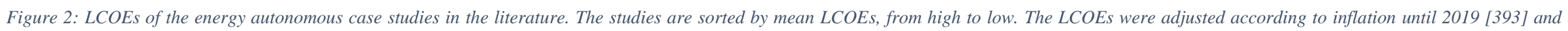

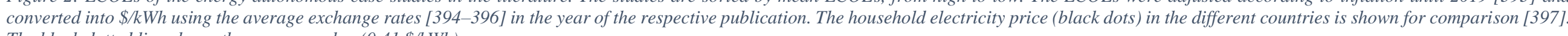
The black dotted line shows the average value $(0.41 \$ / \mathrm{kWh})$. 


\section{Critical appraisal of energy autonomy studies}

In this section, some of the key findings of section 4 are subjected to further critical evaluation. Firstly, though it is difficult to generalize across all 123 reviewed studies, some emerging trends may be highlighted:

- Mostly conventional/established technologies are analysed, with less attention paid to emerging but potentially game-changing technologies such as deep geothermal and fuel cell vehicles;

- The sectoral focus is on residential, with much less consideration of industrial and transportation sectors;

- Network infrastructure is rarely considered, including electricity, gas and heat/cooling;

- Only a minority of studies account for the existing infrastructure as well as the transition from this state to some improved future state along a transition pathway;

- Most studies focus on complete energy autonomy, with some (12\%) dealing with balanced energy autonomy.

The time resolution of most studies is hourly, with one study going into more detail at the 15 -minute level. For long-term planning purposes, the hourly resolution is suitable, but it should also be combined with more detailed analyses and/or information reduction techniques to generate time typologies and synthetic time slices. There is an established stream of research focussing on the most suitable/required time resolution for specific research questions, for energy systems with significant renewable generation fractions (e.g. [396,397]). Studies addressing regional and local energy autonomy could also benefit from exploring such approaches. Otherwise there is a danger that systems are incorrectly dimensioned and are inadequate to ensure supply security in times of peak demand, which for autonomous/off-grid systems is potentially critical.

There is also a lack of attention paid to non-economic and non-technical criteria in studies of energy autonomy at the local scale. Indeed, economic criteria are arguably the most important, but although they are necessary, they are not sufficient. In section 1, among others, it has already been highlighted that certain areas are very far from the national grid and therefore a stand-alone system is appropriate. In this case, the focus on costs as a target criterion is justified, however, the comparison of complete autonomy with the grid connection case should always be demonstrated. Otherwise, in future analyses of energy autonomy more criteria than costs need to be considered. There are other important reasons for municipalities to become energy autonomous besides costs, such as increased environmental awareness (cf. section 1). Furthermore, a comparison with the electricity price in section 4.7 shows that energy autonomy usually leads to significantly higher costs, and thus from a cost perspective there is no potential for energy autonomy.

In terms of the modelling approaches employed for highly renewable, autonomous energy systems there is a clear dominance of linear programming (i.e. optimization) and simulation (i.e. dispatch rules for energy balancing), from a central planner perspective. It is encouraging to find that many researchers are also capturing the noneconomic criteria such as health, noise, water and acceptance issues (cf. Table 7). However, these contributions are still in the minority of those reviewed here, and the overwhelming majority do not satisfactorily reflect the true complexity encountered in real-world energy transitions. It is common practice to leave stakeholder roles outside the scope of the studies or models and to calculate optimal autonomy transition pathways with a centralized 
planning approach under the selected objective of technical feasibility and economic viability. However, local energy systems are complex socio-technical systems consisting of different decision-making entities and technological artefacts governed by energy policy in a multi-level institutional space [12]. Social relationships among the stakeholders represent a major driver or barrier as also stated by previous reviews [4]. In this context, adoption behaviour approaches are useful to understand the types of barriers that exist for new technologies, and what kind of policies are important to increase diffusion. As a consequence, realising the potential of local energy autonomy is not simply a question of technical realities but also a question of individual behaviour and group dynamics. Relevant local stakeholders as households or communities, energy producers, energy suppliers, service providers, as well as local policy-makers are inter-dependent in the realization of their goals. Future system models need to include the heterogeneous roles different stakeholders play in an existing local environment and the resulting impact their decision making might have. One possible solution could be the extension of the presented techno-economic modelling approaches with the help of socio-economic modelling approaches as agent-based models [398,399] or system dynamics models [400].

Many different spatial scales (e.g. number of households) have been considered in the case studies (cf. section 4.2.1). Whilst the optimal spatial size of an energy autonomous region has not yet been identified, it is interesting to note that the mean number of households and inhabitants in energy-autonomous regions is 340 and 18,200 , respectively (based on the 56 and 49 articles containing this information, respectively). This is strongly linked to the question of the optimal degree of centralisation [401]. Concerning demand and consumption sectors there is also some potential for improvement (cf. section 4.2). The demand product water, for example, which is strongly linked to energy, or the consumption sector industry is only very rarely taken into account. For the latter, transferable methods to determine the energy demand and load profile of industries in arbitrary regions could facilitate its implementation. The transport sector is also almost completely ignored in studies about local energy autonomy. A particularly interesting approach would be to optimize the number and use of electric or fuel cell vehicles. In general, however, all sectors should be taken into account, especially when estimating the impact of one or many energy autonomous regions on the surrounding energy system.

Validation is challenging in the context of local energy systems, which might explain why very few existing studies attempt to do this. Often detailed data on the existing energy system is lacking and validation for some hypothetical future scenario is obviously not meaningful. Model design and data assumptions of studies used to gain insights to form the decision making should be transparent and accessible. This not only allows independent review of various stakeholders but also the complete reproducibility of the results [402]. Whilst there is a strong trend towards open-source models and data within the wider energy system modelling field [403], of the reviewed models, none appear to be fully open source, with Homer and EnergyPlan only being open access. Hence local energy autonomy studies could increase efforts to publicly release data and system models as well as assumptions and results interpretation, in order that diverse affected stakeholders are able to participate in the decision-making process $[402,404]$.

In addition, the focus on the LCOEs as a benchmark for highly-renewable energy systems could provide potentially misleading results. Whilst the LCOE is a good first indicator of the generation costs and allows comparisons across 
technology, it is noted for neglecting the additional costs of integrating non-dispatchable renewable technologies into the energy system. Three additional cost components should be considered, if the true system LCOEs of renewable energy technologies are to be considered [405,406]:

- Profiling costs, related to the requirement for the dispatchable generation technologies to meet the residual load;

- Balancing costs, related to the deviation between forecast and actual non-dispatchable renewable generation; and

- Grid costs, related to addition grid reinforcement and extension (at all voltage levels) required to connect renewable generators to the network.

Attempts have been made to consider these cost components in the context of large-scale (e.g. national) energy system analyses (e.g. [407-409]). However, at the regional and municipal scale, as demonstrated by this review, they are typically not included. This is despite the fact that, when considering balanced autonomy, these effects on the surrounding energy system are of particular importance. Balanced energy autonomy and the associated increasing feed-in by renewables could make network expansion even more essential and also make new allocation systems for grid fees necessary [401]. The result could be economic inefficiencies compared to the established system of centralised generation, transmission and distribution [410]. However, possible energy system impacts were not considered in any of the 14 studies on balanced autonomy. Hence there is a need for further research to address these and the above mentioned deficits.

\section{Summary and conclusions}

Research attention on decentralized autonomous energy systems has increased exponentially in the past three decades, as demonstrated by the absolute number of publications and the share of these studies in the corpus of energy system modelling literature. This paper shows the status quo and future modelling needs for research on local autonomous energy systems. A total of 359 studies are roughly investigated, of which a subset of 123 in detail. The studies are assessed with respect to the characteristics of their methodology and applications, in order to derive common trends and insights.

The results show that most case studies were conducted in the middle-income countries India, Iran and China as well as the high-income country Germany. In the middle-income country studies, mostly remote rural areas without electricity network connection are considered, whereas in high-income countries the case studies are much more diverse and also include cities and islands. In addition, most studies only focus on the residential sector and the supply of electricity. A wide range of technologies has already been covered in the literature, including less common technologies such as power-to-gas and fuel cell vehicles. However, the network infrastructure is rarely considered. The levelized costs of electricity for local autonomous energy systems in 83 case studies amount to $0.41 \$ / \mathrm{kWh}$ on average. Thereby, studies are identified in which the resulting costs should be questioned, as they deviate strongly from the average.

In terms of the employed methodology, most of the reviewed literature reports an optimization or simulation approach, with a central planner perspective. They typically employ a time resolution of one hour, but for some 
studies also increase this to 15-minute resolution. Whilst it is commendable that some of the studies also consider non-economic criteria such as social and environmental aspects, neither the system-level impacts nor the diverse stakeholders are included in most works. Furthermore, there is a general lack of transparency across most reviewed literature, meaning that neither open data nor open models are widely applied to local energy systems.

Hence, future research should focus on the following methodological innovations. Other perspectives than that of a central planner and other target criteria than costs should be included. This could contribute to the realizability of the case study results. System impacts of many local autonomous energy systems have not yet been investigated, which could make new distribution systems and grid fees necessary. Complete autonomous energy systems in particular must be robustly designed, for example by analysing the value of lost load and whether a security of supply below $100 \%$ is acceptable for consumers of the case study, preferably using penalty costs for unmet load in the target function. In addition, extreme conditions such as extreme days with low solar radiation or wind should be considered and the temporal resolution should be higher than the usually used hourly resolution. Finally, methodologies should be developed which can involve local stakeholders in the modelling process and thus consider their preferences relating to their future energy system.

\section{Acknowledgements}

Fabian Scheller receives funding from the European Union's Horizon 2020 research and innovation programme under the Marie Sklodowska-Curie grant agreement no. 713683 (COFUNDfellowsDTU). Russell McKenna and Fabian Scheller kindly acknowledge the financial support of the FlexSUS Project (Project nbr. 91352), which has received funding in the framework of the joint programming initiative ERA-Net Smart Energy Systems' focus initiative Integrated, Regional Energy Systems, with support from the European Union's Horizon 2020 research and innovation programme under grant agreement No 775970. Russell McKenna also gratefully acknowledges the support of the Smart City Accelerator project. The usual disclaimer applies.

\section{References}

[1] International Energy Agency. Energy access database. [October 22, 2019]; Available from: https://www.iea.org/energyaccess/database/.

[2] International Energy Agency. Energy Access Outlook 2017: From Poverty to Prosperity. [October 22, 2019]; Available from: https://www.iea.org/publications/freepublications/publication/WEO2017SpecialReport_EnergyAccessOutlook.pdf.

[3] The World Bank. Access to electricity (\% of population). [October 22, 2019]; Available from: https://data.worldbank.org/indicator/eg.Elc.Accs.Zs.

[4] Rae C, Bradley F. Energy autonomy in sustainable communities - A review of key issues. Renewable and Sustainable Energy Reviews 2012;16(9):6497-506. https://doi.org/10.1016/j.rser.2012.08.002.

[5] Engelken M, Römer B, Drescher M, Welpe I. Transforming the energy system: Why municipalities strive for energy selfsufficiency. Energy Policy 2016;98:365-77. https://doi.org/10.1016/j.enpol.2016.07.049.

[6] Boon FP, Dieperink C. Local civil society based renewable energy organisations in the Netherlands: Exploring the factors that stimulate their emergence and development. Energy Policy 2014;69:297-307. https://doi.org/10.1016/j.enpol.2014.01.046.

[7] Volz R. Bedeutung und Potenziale von Energiegenossenschaften in Deutschland - eine empirische Aufbereitung. Informationen zur Raumentwicklung 515-524;9(10).

[8] Weinand JM, McKenna R, Kleinebrahm M, Mainzer K. Assessing the contribution of simultaneous heat and power generation from geothermal plants in off-grid municipalities. Applied Energy 2019;255:113824. https://doi.org/10.1016/j.apenergy.2019.113824.

[9] Keirstead J, Jennings M, Sivakumar A. A review of urban energy system models: Approaches, challenges and opportunities. Renewable and Sustainable Energy Reviews 2012;16(6):3847-66. https://doi.org/10.1016/j.rser.2012.02.047.

[10] Mirakyan A, Guio R de. Integrated energy planning in cities and territories: A review of methods and tools. Renewable and Sustainable Energy Reviews 2013;22:289-97. https://doi.org/10.1016/j.rser.2013.01.033.

[11] Gamarra C, Guerrero JM. Computational optimization techniques applied to microgrids planning: A review. Renewable and Sustainable Energy Reviews 2015;48:413-24. https://doi.org/10.1016/j.rser.2015.04.025. 
[12] Koirala BP, Koliou E, Friege J, Hakvoort RA, Herder PM. Energetic communities for community energy: A review of key issues and trends shaping integrated community energy systems. Renewable and Sustainable Energy Reviews 2016;56:722-44. https://doi.org/10.1016/j.rser.2015.11.080.

[13] Scheller F, Bruckner T. Energy system optimization at the municipal level: An analysis of modeling approaches and challenges. Renewable and Sustainable Energy Reviews 2019;105:444-61. https://doi.org/10.1016/j.rser.2019.02.005.

[14] Huang Z, Yu H, Peng Z, Zhao M. Methods and tools for community energy planning: A review. Renewable and Sustainable Energy Reviews 2015;42:1335-48. https://doi.org/10.1016/j.rser.2014.11.042.

[15] Allan G, Eromenko I, Gilmartin M, Kockar I, McGregor P. The economics of distributed energy generation: A literature review. Renewable and Sustainable Energy Reviews 2015;42:543-56. https://doi.org/10.1016/j.rser.2014.07.064.

[16] Müller MO, Stämpfli A, Dold U, Hammer T. Energy autarky: A conceptual framework for sustainable regional development. Energy Policy 2011;39(10):5800-10. https://doi.org/10.1016/j.enpol.2011.04.019.

[17] Kaundinya DP, Balachandra P, Ravindranath NH. Grid-connected versus stand-alone energy systems for decentralized power-A review of literature. Renewable and Sustainable Energy Reviews 2009;13(8):2041-50. https://doi.org/10.1016/j.rser.2009.02.002.

[18] Brown TW, Bischof-Niemz T, Blok K, Breyer C, Lund H, Mathiesen BV. Response to 'Burden of proof: A comprehensive review of the feasibility of 100\% renewable-electricity systems'. Renewable and Sustainable Energy Reviews 2018;92:834-47. https://doi.org/10.1016/j.rser.2018.04.113.

[19] Hansen K, Breyer C, Lund H. Status and perspectives on 100\% renewable energy systems. Energy 2019;175:471-80. https://doi.org/10.1016/j.energy.2019.03.092.

[20] Heard BP, Brook BW, Wigley T, Bradshaw C. Burden of proof: A comprehensive review of the feasibility of $100 \%$ renewableelectricity systems. Renewable and Sustainable Energy Reviews 2017;76:1122-33. https://doi.org/10.1016/j.rser.2017.03.114.

[21] Nakata T, Silva D, Rodionov M. Application of energy system models for designing a low-carbon society. Progress in Energy and Combustion Science 2011;37(4):462-502. https://doi.org/10.1016/j.pecs.2010.08.001.

[22] Engelken M, Römer B, Drescher M, Welpe IM, Picot A. Comparing drivers, barriers, and opportunities of business models for renewable energies: A review. Renewable and Sustainable Energy Reviews 2016;60:795-809. https://doi.org/10.1016/j.rser.2015.12.163.

[23] Falagas ME, Pitsouni EI, Malietzis GA, Pappas G. Comparison of PubMed, Scopus, Web of Science, and Google Scholar: Strengths and weaknesses. FASEB J 2008;22(2):338-42. https://doi.org/10.1096/fj.07-9492LSF.

[24] Chappin EJ, Ligtvoet A. Transition and transformation: A bibliometric analysis of two scientific networks researching sociotechnical change. Renewable and Sustainable Energy Reviews 2014;30:715-23. https://doi.org/10.1016/j.rser.2013.11.013.

[25] Abdul-Wahab S, Mujezinovic K, Al-Mahruqi AM. Optimal design and evaluation of a hybrid energy system for off-grid remote area. Energy Sources, Part A: Recovery, Utilization, and Environmental Effects 2019;7(25):1-13. https://doi.org/10.1080/15567036.2019.1656308.

[26] Abnavi MD, Mohammadshafie N, Rosen MA, Dabbaghian A, Fazelpour F. Techno-economic feasibility analysis of stand-alone hybrid wind/photovoltaic/diesel/battery system for the electrification of remote rural areas: Case study Persian Gulf Coast-Iran. Environ Prog Sustainable Energy 2019;38(5):13172. https://doi.org/10.1002/ep.13172.

[27] Adaramola MS, Agelin-Chaab M, Paul SS. Analysis of hybrid energy systems for application in southern Ghana. Energy Conversion and Management 2014;88:284-95. https://doi.org/10.1016/j.enconman.2014.08.029.

[28] Adaramola MS, Oyewola OM, Paul SS. Technical and Economic Assessment of Hybrid Energy Systems in South-West Nigeria. ENERGY EXPLORATION \& EXPLOITATION 2012;30(4):533-52.

[29] Adaramola MS, Quansah DA, Agelin-Chaab M, Paul SS. Multipurpose renewable energy resources based hybrid energy system for remote community in northern Ghana. Sustainable Energy Technologies and Assessments 2017;22:161-70. https://doi.org/10.1016/j.seta.2017.02.011.

[30] Afzal A, Mohibullah M, Kumar Sharma V. Optimal hybrid renewable energy systems for energy security: A comparative study. International Journal of Sustainable Energy 2010;29(1):48-58. https://doi.org/10.1080/14786460903337241.

[31] Alhamwi A, Medjroubi W, Vogt T, Agert C. Development of a GIS-based platform for the allocation and optimisation of distributed storage in urban energy systems. Applied Energy 2019;251:113360. https://doi.org/10.1016/j.apenergy.2019.113360.

[32] Al-Shetwi AQ, Sujod MZ, Al Tarabsheh A, Altawil IA. Design and Economic Evaluation of Electrification of Small Villages in Rural Area in Yemen Using Stand-Alone PV System. International Journal of Renewable Energy Research 2016;6(1):289-98.

[33] Arefin SS, Das N. Optimized Hybrid Wind-Diesel Energy System with Feasibility Analysis. Technol Econ Smart Grids Sustain Energy 2017;2(1):63. https://doi.org/10.1007/s40866-017-0025-6.

[34] Ashok S. Optimised model for community-based hybrid energy system. Renewable Energy 2007;32(7):1155-64. https://doi.org/10.1016/j.renene.2006.04.008.

[35] Askari IB, Ameri M. Optimal sizing of photovoltaic - battery power systems in a remote region in Kerman, Iran. Proceedings of the Institution of Mechanical Engineers, Part A: Journal of Power and Energy 2009;223(5):563-70. https://doi.org/10.1243/09576509JPE717.

[36] Askari IB, Ameri M. Techno-economic Feasibility Analysis of Stand-alone Renewable Energy Systems (PV/bat, Wind/bat and Hybrid PV/wind/bat) in Kerman, Iran. Energy Sources, Part B: Economics, Planning, and Policy 2012;7(1):45-60. https://doi.org/10.1080/15567240903330384.

[37] Askarzadeh A, dos Santos Coelho L. A novel framework for optimization of a grid independent hybrid renewable energy system: A case study of Iran. Solar Energy 2015;112:383-96. https://doi.org/10.1016/j.solener.2014.12.013.

[38] Azaza M, Wallin F. Multi objective particle swarm optimization of hybrid micro-grid system: A case study in Sweden. Energy 2017;123:108-18. https://doi.org/10.1016/j.energy.2017.01.149.

[39] Bagheri M, Delbari SH, Pakzadmanesh M, Kennedy CA. City-integrated renewable energy design for low-carbon and climateresilient communities. Applied Energy 2019;239:1212-25. https://doi.org/10.1016/j.apenergy.2019.02.031. 
[40] Bagheri M, Shirzadi N, Bazdar E, Kennedy CA. Optimal planning of hybrid renewable energy infrastructure for urban sustainability: Green Vancouver. Renewable and Sustainable Energy Reviews 2018;95:254-64. https://doi.org/10.1016/j.rser.2018.07.037.

[41] Balaji V, Gurgenci H. Search for optimum renewable mix for Australian off-grid power generation. Energy 2019;175:1234-45. https://doi.org/10.1016/j.energy.2019.03.089.

[42] Baneshi M, Hadianfard F. Techno-economic feasibility of hybrid diesel/PV/wind/battery electricity generation systems for nonresidential large electricity consumers under southern Iran climate conditions. Energy Conversion and Management 2016;127:23344. https://doi.org/10.1016/j.enconman.2016.09.008.

[43] Baseer MA, Alqahtani A, Rehman S. Techno-economic design and evaluation of hybrid energy systems for residential communities: Case study of Jubail industrial city. Journal of Cleaner Production 2019;237:117806. https://doi.org/10.1016/j.jclepro.2019.117806.

[44] Bentouba S, Bourouis M. Feasibility study of a wind-photovoltaic hybrid power generation system for a remote area in the extreme south of Algeria. Applied Thermal Engineering 2016;99:713-9. https://doi.org/10.1016/j.applthermaleng.2015.12.014.

[45] Bonati A, Luca G de, Fabozzi S, Massarotti N, Vanoli L. The integration of exergy criterion in energy planning analysis for $100 \%$ renewable system. Energy 2019;174:749-67. https://doi.org/10.1016/j.energy.2019.02.089.

[46] Castellanos JG, Walker M, Poggio D, Pourkashanian M, Nimmo W. Modelling an off-grid integrated renewable energy system for rural electrification in India using photovoltaics and anaerobic digestion. Renewable Energy 2015;74:390-8. https://doi.org/10.1016/j.renene.2014.08.055.

[47] Chauhan A, Saini RP. Techno-economic optimization based approach for energy management of a stand-alone integrated renewable energy system for remote areas of India. Energy 2016;94:138-56. https://doi.org/10.1016/j.energy.2015.10.136.

[48] Chauhan A, Saini RP. Size optimization and demand response of a stand-alone integrated renewable energy system. Energy 2017;124:59-73. https://doi.org/10.1016/j.energy.2017.02.049.

[49] Chmiel Z, Bhattacharyya SC. Analysis of off-grid electricity system at Isle of Eigg (Scotland): Lessons for developing countries. Renewable Energy 2015;81:578-88. https://doi.org/10.1016/j.renene.2015.03.061.

[50] Clark W, Isherwood W. Distributed generation: Remote power systems with advanced storage technologies. Energy Policy 2004;32(14):1573-89. https://doi.org/10.1016/S0301-4215(03)00017-X.

[51] Das BK, Hoque N, Mandal S, Pal TK, Raihan MA. A techno-economic feasibility of a stand-alone hybrid power generation for remote area application in Bangladesh. Energy 2017;134:775-88. https://doi.org/10.1016/j.energy.2017.06.024.

[52] Dorotić H, Doračić B, Dobravec V, Pukšec T, Krajačić G, Duić N. Integration of transport and energy sectors in island communities with 100\% intermittent renewable energy sources. Renewable and Sustainable Energy Reviews 2019;99:109-24. https://doi.org/10.1016/j.rser.2018.09.033.

[53] Drysdale D, Vad Mathiesen B, Lund H. From Carbon Calculators to Energy System Analysis in Cities. Energies 2019;12(12):2307. https://doi.org/10.3390/en12122307.

[54] Dursun B, Gokcol C, Umut I, Ucar E, Kocabey S. Techno-Economic Evaluation of a Hybrid PV_Wind Power Generation System. International Journal of Green Energy 2013;10(2):117-36. https://doi.org/10.1080/15435075.2011.641192.

[55] Fuentes-Cortés LF, Ponce-Ortega JM. Optimal design of energy and water supply systems for low-income communities involving multiple-objectives. Energy Conversion and Management 2017;151:43-52. https://doi.org/10.1016/j.enconman.2017.08.050.

[56] Fulhu M, Mohamed M, Krumdieck S. Voluntary demand participation (VDP) for security of essential energy activities in remote communities with case study in Maldives. Energy for Sustainable Development 2019;49:27-38. https://doi.org/10.1016/j.esd.2019.01.002.

[57] Fuso Nerini F, Dargaville R, Howells M, Bazilian M. Estimating the cost of energy access: The case of the village of Suro Craic in Timor Leste. Energy 2015;79:385-97. https://doi.org/10.1016/j.energy.2014.11.025.

[58] Ganguly P, Kalam A, Zayegh A. Fuzzy logic-based energy management system of stand-alone renewable energy system for a remote area power system. Australian Journal of Electrical and Electronics Engineering 2019;16(1):21-32. https://doi.org/10.1080/1448837X.2019.1588091.

[59] Gupta A, Saini RP, Sharma MP. Steady-state modelling of hybrid energy system for off grid electrification of cluster of villages. Renewable Energy 2010;35(2):520-35. https://doi.org/10.1016/j.renene.2009.06.014.

[60] Gupta A, Saini RP, Sharma MP. Modelling of hybrid energy system-Part III: Case study with simulation results. Renewable Energy 2011;36(2):474-81. https://doi.org/10.1016/j.renene.2009.04.036.

[61] Haghighat Mamaghani A, Avella Escandon SA, Najafi B, Shirazi A, Rinaldi F. Techno-economic feasibility of photovoltaic, wind, diesel and hybrid electrification systems for off-grid rural electrification in Colombia. Renewable Energy 2016;97:293-305. https://doi.org/10.1016/j.renene.2016.05.086.

[62] Hakimi SM, Moghaddas-Tafreshi SM, HassanzadehFard H. Optimal sizing of reliable hybrid renewable energy system considered various load types. Journal of Renewable and Sustainable Energy 2011;3(6):62701. https://doi.org/10.1063/1.3655372.

[63] Halabi LM, Mekhilef S. Flexible hybrid renewable energy system design for a typical remote village located in tropical climate. Journal of Cleaner Production 2018;177:908-24. https://doi.org/10.1016/j.jclepro.2017.12.248.

[64] Heydari A, Askarzadeh A. Techno-economic analysis of a PV/biomass/fuel cell energy system considering different fuel cell system initial capital costs. Solar Energy 2016;133:409-20. https://doi.org/10.1016/j.solener.2016.04.018.

[65] Ho WS, Hashim H, Hassim MH, Muis ZA, Shamsuddin N. Design of distributed energy system through Electric System Cascade Analysis (ESCA). Applied Energy 2012;99:309-15. https://doi.org/10.1016/j.apenergy.2012.04.016.

[66] Hosseini SJ, Moazzami M, Shahinzadeh H. Optimal Sizing of an Isolated Hybrid Wind/PV/Battery System with Considering Loss of Power Supply Probability. Majlesi Journal of Electrical Engineering 2017;11(3):63-9.

[67] Bekele G, Palm B. Feasibility study for a standalone solar-wind-based hybrid energy system for application in Ethiopia. Applied Energy 2010;87(2):487-95. https://doi.org/10.1016/j.apenergy.2009.06.006. 
[68] Iaquaniello G, Montanari W, Salladini A. Standalone CSP-DG system for electrification of remote areas and desalinated water supply. Solar Energy 2017;157:1056-63. https://doi.org/10.1016/j.solener.2017.09.026.

[69] Jamshidi M, Askarzadeh A. Techno-economic analysis and size optimization of an off-grid hybrid photovoltaic, fuel cell and diesel generator system. Sustainable Cities and Society 2019;44:310-20. https://doi.org/10.1016/j.scs.2018.10.021.

[70] Javed MS, Song A, Ma T. Techno-economic assessment of a stand-alone hybrid solar-wind-battery system for a remote island using genetic algorithm. Energy 2019;176:704-17. https://doi.org/10.1016/j.energy.2019.03.131.

[71] Jenssen T, König A, Eltrop L. Bioenergy villages in Germany: Bringing a low carbon energy supply for rural areas into practice. Renewable Energy 2014;61:74-80. https://doi.org/10.1016/j.renene.2012.08.014.

[72] Kamran M, Asghar R, Mudassar M, Ahmed SR, Fazal MR, Abid MI et al. Designing and Optimization of Stand-alone Hybrid Renewable Energy System for Rural Areas of Punjab, Pakistan. International Journal of Renewable Energy Research 2018;8(4):2585-97.

[73] Kanase-Patil AB, Saini RP, Sharma MP. Integrated renewable energy systems for off grid rural electrification of remote area. Renewable Energy 2010;35(6):1342-9. https://doi.org/10.1016/j.renene.2009.10.005.

[74] Kanase-Patil AB, Saini RP, Sharma MP. Development of IREOM model based on seasonally varying load profile for hilly remote areas of Uttarakhand state in India. Energy 2011;36(9):5690-702. https://doi.org/10.1016/j.energy.2011.06.057.

[75] Kandil MS, Farghal SA, El-Alfy AE. Optimum Operation of an Autonomous Energy System Suitable for New Communities in Developing Countries. Electric Power Systems Research 1991;21:137-46.

[76] Khan AN, Akhter P, Mufti GM. Techno-Economic Evaluation of the Centralized Hybrid Renewable Energy Systems for Off-Grid Rural Electrification. International Journal of Smart Home 2016;10(5):61-8. https://doi.org/10.14257/ijsh.2016.10.5.07.

[77] Kim H, Baek S, Choi K, Kim D, Lee S, Kim D et al. Comparative Analysis of On- and Off-Grid Electrification: The Case of Two South Korean Islands. Sustainability 2016;8(4):350. https://doi.org/10.3390/su8040350.

[78] Kobayakawa T, Kandpal TC. Optimal resource integration in a decentralized renewable energy system: Assessment of the existing system and simulation for its expansion. Energy for Sustainable Development 2016;34:20-9. https://doi.org/10.1016/j.esd.2016.06.006.

[79] Kötter E, Schneider L, Sehnke F, Ohnmeiss K, Schröer R. The future electric power system: Impact of Power-to-Gas by interacting with other renewable energy components. Journal of Energy Storage 2016;5:113-9. https://doi.org/10.1016/j.est.2015.11.012.

[80] Krajačić G, Duić N, Carvalho MdG. H2RES, Energy planning tool for island energy systems - The case of the Island of Mljet is. International Journal of Hydrogen Energy 2009;34(16):7015-26. https://doi.org/10.1016/j.ijhydene.2008.12.054.

[81] Kumar A, Singh AR, Deng Y, He X, Kumar P, Bansal RC. Integrated assessment of a sustainable microgrid for a remote village in hilly region. Energy Conversion and Management 2019;180:442-72. https://doi.org/10.1016/j.enconman.2018.10.084.

[82] Kumaravel S, Ashok S. An Optimal Stand-Alone Biomass/Solar-PV/Pico-Hydel Hybrid Energy System for Remote Rural Area Electrification of Isolated Village in Western-Ghats Region of India. International Journal of Green Energy 2012;9(5):398-408. https://doi.org/10.1080/15435075.2011.621487.

[83] Li C. Techno-economic study of off-grid hybrid photovoltaic/battery and photovoltaic/battery/fuel cell power systems in Kunming, China. Energy Sources, Part A: Recovery, Utilization, and Environmental Effects 2018;41(13):1588-604. https://doi.org/10.1080/15567036.2018.1549134.

[84] Lu J, Wang W, Zhang Y, Cheng S. Multi-Objective Optimal Design of Stand-Alone Hybrid Energy System Using Entropy Weight Method Based on HOMER. Energies 2017;10(10):1664. https://doi.org/10.3390/en10101664.

[85] Ma T, Javed MS. Integrated sizing of hybrid PV-wind-battery system for remote island considering the saturation of each renewable energy resource. Energy Conversion and Management 2019;182:178-90. https://doi.org/10.1016/j.enconman.2018.12.059.

[86] Ma T, Yang H, Lu L, Peng J. Technical feasibility study on a standalone hybrid solar-wind system with pumped hydro storage for a remote island in Hong Kong. Renewable Energy 2014;69:7-15. https://doi.org/10.1016/j.renene.2014.03.028.

[87] Ma T, Yang H, Lu L. Study on stand-alone power supply options for an isolated community. International Journal of Electrical Power \& Energy Systems 2015;65:1-11. https://doi.org/10.1016/j.ijepes.2014.09.023.

[88] Mahapatra S, Dasappa S. Rural electrification: Optimising the choice between decentralised renewable energy sources and grid extension. Energy for Sustainable Development 2012;16(2):146-54. https://doi.org/10.1016/j.esd.2012.01.006.

[89] Maleki A, Askarzadeh A. Optimal sizing of a PV/wind/diesel system with battery storage for electrification to an off-grid remote region: A case study of Rafsanjan, Iran. Sustainable Energy Technologies and Assessments 2014;7:147-53. https://doi.org/10.1016/j.seta.2014.04.005.

[90] Maleki A, Pourfayaz F, Ahmadi MH. Design of a cost-effective wind/photovoltaic/hydrogen energy system for supplying a desalination unit by a heuristic approach. Solar Energy 2016;139:666-75. https://doi.org/10.1016/j.solener.2016.09.028.

[91] Maleki A, Pourfayaz F, Hafeznia H, Rosen MA. A novel framework for optimal photovoltaic size and location in remote areas using a hybrid method: A case study of eastern Iran. Energy Conversion and Management 2017;153:129-43. https://doi.org/10.1016/j.enconman.2017.09.061.

[92] Mandal S, Das BK, Hoque N. Optimum sizing of a stand-alone hybrid energy system for rural electrification in Bangladesh. Journal of Cleaner Production 2018;200:12-27. https://doi.org/10.1016/j.jclepro.2018.07.257.

[93] McKenna R, Bertsch V, Mainzer K, Fichtner W. Combining local preferences with multi-criteria decision analysis and linear optimization to develop feasible energy concepts in small communities. European Journal of Operational Research 2018;268(3):1092-110. https://doi.org/10.1016/j.ejor.2018.01.036.

[94] Mishra R, Singh S. Sustainable Energy Plan for a Village in Punjab for Self Energy Generation. International Journal of Renewable Energy Research 2013;3(3):640-6.

[95] Moeller C, Meiss J, Mueller B, Hlusiak M, Breyer C, Kastner M et al. Transforming the electricity generation of the BerlinBrandenburg region, Germany. Renewable Energy 2014;72:39-50. https://doi.org/10.1016/j.renene.2014.06.042. 
[96] Muh E, Tabet F. Comparative analysis of hybrid renewable energy systems for off-grid applications in Southern Cameroons. Renewable Energy 2019;135:41-54. https://doi.org/10.1016/j.renene.2018.11.105.

[97] Nigussie T, Bogale W, Bekele F, Dribssa E. Feasibility study for power generation using off- grid energy system from micro hydroPV-diesel generator-battery for rural area of Ethiopia: The case of Melkey Hera village, Western Ethiopia. AIMS Energy 2017;5(4):667-90. https://doi.org/10.3934/energy.2017.4.667.

[98] Nour M, Rohani G. Prospect of Stand-Alone PV-Diesel Hybrid Power System for Rural Electrification in UAE. International Journal of Renewable Energy Research 2014;4(3):749-58.

[99] Ocon JD, Cruz SMM, Castro MT, Aviso KB, Tan RR, Promentilla MAB. Optimal Multi-criteria Selection of Hybrid Energy Systems for Off-grid Electrification. Chemical Engineering Transactions 2018;70:367-72.

[100] Oldenbroek V, Verhoef LA, van Wijk AJ. Fuel cell electric vehicle as a power plant: Fully renewable integrated transport and energy system design and analysis for smart city areas. International Journal of Hydrogen Energy 2017;42(12):8166-96. https://doi.org/10.1016/j.ijhydene.2017.01.155.

[101] Østergaard PA, Lund H. A renewable energy system in Frederikshavn using low-temperature geothermal energy for district heating. Applied Energy 2011;88(2):479-87. https://doi.org/10.1016/j.apenergy.2010.03.018.

[102] Patel AM, Singal SK. Economic Analysis of Integrated Renewable Energy System for Electrification of Remote Rural Area having Scattered Population. International Journal of Renewable Energy Research 2018;8(1):524-39.

[103] Petrakopoulou F, Robinson A, Loizidou M. Exergetic analysis and dynamic simulation of a solar-wind power plant with electricity storage and hydrogen generation. Journal of Cleaner Production 2016;113:450-8. https://doi.org/10.1016/j.jclepro.2015.11.074.

[104] Petrakopoulou F, Robinson A, Loizidou M. Simulation and analysis of a stand-alone solar-wind and pumped-storage hydropower plant. Energy 2016;96:676-83. https://doi.org/10.1016/j.energy.2015.12.049.

[105] Peura P, Haapanen A, Reini K, Törmä H. Regional impacts of sustainable energy in western Finland. Journal of Cleaner Production 2018;187:85-97. https://doi.org/10.1016/j.jclepro.2018.03.194.

[106] Rahman MM, Khan MM-U-H, Ullah MA, Zhang X, Kumar A. A hybrid renewable energy system for a North American off-grid community. Energy 2016;97:151-60. https://doi.org/10.1016/j.energy.2015.12.105.

[107] Rajanna S, Saini RP. Modeling of integrated renewable energy system for electrification of a remote area in India. Renewable Energy 2016;90:175-87. https://doi.org/10.1016/j.renene.2015.12.067.

[108] Ramchandran N, Pai R, Parihar AKS. Feasibility assessment of Anchor-Business-Community model for off-grid rural electrification in India. Renewable Energy 2016;97:197-209. https://doi.org/10.1016/j.renene.2016.05.036.

[109] Ramli MAM, Hiendro A, Bouchekara HREH. Performance Analysis of Hybrid PV/Diesel Energy System in Western Region of Saudi Arabia. International Journal of Photoenergy 2014;2014(12):1-10. https://doi.org/10.1155/2014/626251.

[110] Ray A, Jana K, De S. Polygeneration for an off-grid Indian village: Optimization by economic and reliability analysis. Applied Thermal Engineering 2017;116:182-96. https://doi.org/10.1016/j.applthermaleng.2016.11.020.

[111] Rehman SU, Rehman S, Qazi MU, Shoaib M, Lashin A. Feasibility study of hybrid energy system for off-grid rural electrification in southern Pakistan. ENERGY EXPLORATION \& EXPLOITATION 2016;34(3):468-82. https://doi.org/10.1177/0144598716630176.

[112] Rohani G, Nour M. Techno-economical analysis of stand-alone hybrid renewable power system for Ras Musherib in United Arab Emirates. Energy 2014;64:828-41. https://doi.org/10.1016/j.energy.2013.10.065.

[113] Sameti M, Haghighat F. Integration of distributed energy storage into net-zero energy district systems: Optimum design and operation. Energy 2018;153:575-91. https://doi.org/10.1016/j.energy.2018.04.064.

[114] Samy MM, Barakat S, Ramadan HS. A flower pollination optimization algorithm for an off-grid PV-Fuel cell hybrid renewable system. International Journal of Hydrogen Energy 2019;44(4):2141-52. https://doi.org/10.1016/j.ijhydene.2018.05.127.

[115] Sanajaoba S. Optimal sizing of off-grid hybrid energy system based on minimum cost of energy and reliability criteria using firefly algorithm. Solar Energy 2019;188:655-66. https://doi.org/10.1016/j.solener.2019.06.049.

[116] Sanajaoba Singh S, Fernandez E. Modeling, size optimization and sensitivity analysis of a remote hybrid renewable energy system. Energy 2018;143:719-31. https://doi.org/10.1016/j.energy.2017.11.053.

[117] Šare A, Krajačić G, Pukšec T, Duić N. The integration of renewable energy sources and electric vehicles into the power system of the Dubrovnik region. Energ Sustain Soc 2015;5(1):17. https://doi.org/10.1186/s13705-015-0055-7.

[118] Schmidt J, Schönhart M, Biberacher M, Guggenberger T, Hausl S, Kalt G et al. Regional energy autarky: Potentials, costs and consequences for an Austrian region. Energy Policy 2012;47:211-21. https://doi.org/10.1016/j.enpol.2012.04.059.

[119] Sepulveda TT, Martinez L. Optimization of a Hybrid Energy System for an Isolated Community in Brazil. International Journal of Renewable Energy Research 2016;6(4):1476-81.

[120] Shezan SA. Optimization and assessment of an off-grid photovoltaic-diesel-battery hybrid sustainable energy system for remote residential applications. Environ Prog Sustainable Energy 2019;32(2017):100. https://doi.org/10.1002/ep.13340.

[121] Shezan S, Al-Mamoon A, Ping HW. Performance investigation of an advanced hybrid renewable energy system in indonesia. Environ. Prog. Sustainable Energy 2018;37(4):1424-32. https://doi.org/10.1002/ep.12790.

[122] Shezan S, Julai S, Kibria MA, Ullah KR, Saidur R, Chong WT et al. Performance analysis of an off-grid wind-PV (photovoltaic)diesel-battery hybrid energy system feasible for remote areas. Journal of Cleaner Production 2016;125:121-32. https://doi.org/10.1016/j.jclepro.2016.03.014.

[123] Stephen JD, Mabee WE, Pribowo A, Pledger S, Hart R, Tallio S et al. Biomass for residential and commercial heating in a remote Canadian aboriginal community. Renewable Energy 2016;86:563-75. https://doi.org/10.1016/j.renene.2015.08.048.

[124] Waenn A, Connolly D, Ó Gallachóir B. Investigating 100\% renewable energy supply at regional level using scenario analysis. International Journal of Sustainable Energy Planning and Management 2014;3:21-32. https://doi.org/10.5278/IJSEPM.2014.3.3.

[125] Yazdanpanah Jahromi MA, Farahat S, Barakati SM. Optimal size and cost analysis of stand-alone hybrid wind/photovoltaic powergeneration systems. Civil Engineering and Environmental Systems 2013;31(4):283-303. https://doi.org/10.1080/10286608.2013.853752. 
[126] Yazdanpanah-Jahromi MA, Barakati S-M, Farahat S. An efficient sizing method with suitable energy management strategy for hybrid renewable energy systems. Int. Trans. Electr. Energ. Syst. 2014;24(10):1473-92. https://doi.org/10.1002/etep.1790.

[127] Yimen N, Hamandjoda O, Meva'a L, Ndzana B, Nganhou J. Analyzing of a Photovoltaic/Wind/Biogas/Pumped-Hydro Off-Grid Hybrid System for Rural Electrification in Sub-Saharan Africa-Case study of Djoundé in Northern Cameroon. Energies 2018;11(10):2644. https://doi.org/10.3390/en11102644.

[128] Zhang W, Maleki A, Rosen MA, Liu J. Optimization with a simulated annealing algorithm of a hybrid system for renewable energy including battery and hydrogen storage. Energy 2018;163:191-207. https://doi.org/10.1016/j.energy.2018.08.112.

[129] Zhang W, Maleki A, Rosen MA, Liu J. Sizing a stand-alone solar-wind-hydrogen energy system using weather forecasting and a hybrid search optimization algorithm. Energy Conversion and Management 2019;180:609-21. https://doi.org/10.1016/j.enconman.2018.08.102.

[130] Zhao G, Guerrero JM, Jiang K, Chen S. Energy modelling towards low carbon development of Beijing in 2030. Energy 2017;121:107-13. https://doi.org/10.1016/j.energy.2017.01.019.

[131] Lal DK, Dash BB, Akella AK. Optimization of PV/Wind/Micro-Hydro/diesel hybrid power system in homer for the study area. International Journal on Electrical Engineering and Informatics 2011;3(3):307-25.

[132] Galvez GH, Probst O, Lastres O, Rodríguez AN, Ugás AJ, Durán EA et al. Optimization of autonomous hybrid systems with hydrogen storage: Life cycle assessment. International Journal of Energy Research 2012;36(6):749-63. https://doi.org/10.1002/er.1830.

[133] Kumar R, Gupta RA, Bansal AK. Economic analysis and power management of a stand-alone wind/photovoltaic hybrid energy system using biogeography based optimization algorithm. Swarm and Evolutionary Computation 2013;8:33-43. https://doi.org/10.1016/j.swevo.2012.08.002.

[134] Ma T, Yang H, Lu L. A feasibility study of a stand-alone hybrid solar-wind-battery system for a remote island. Applied Energy 2014;121:149-58. https://doi.org/10.1016/j.apenergy.2014.01.090.

[135] Baghdadi F, Mohammedi K, Diaf S, Behar O. Feasibility study and energy conversion analysis of stand-alone hybrid renewable energy system. Energy Conversion and Management 2015;105:471-9. https://doi.org/10.1016/j.enconman.2015.07.051.

[136] Salehin S, Rahman MM, Islam AS. Techno-economic feasibility study of a solar PV-diesel system for applications in Northern part of Bangladesh. International Journal of Renewable Energy Research 2015;5(4):1220-9.

[137] Mas'Ud AA. The application of homer optimization software to investigate the prospects of hybrid renewable energy system in rural communities of sokoto in Nigeria. International Journal of Electrical and Computer Engineering 2017;7(2):596-603. https://doi.org/10.11591/ijece.v7i2.pp596-603.

[138] Aziz AS, bin Tajuddin M, bin Adzman MR, Ramli M. Feasibility analysis of PV/diesel/battery hybrid energy system using multiyear module. International Journal of Renewable Energy Research 2018;8(4):1980-93.

[139] Bashir N, Modu B. Techno-economic analysis of off-grid renewable energy systems for rural electrification in Northeastern Nigeria. International Journal of Renewable Energy Research 2018;8(3):1217-28.

[140] Khan MA, Zeb K, Sathishkumar P, Himanshu L, Srinivasa Rao S, Gopi C et al. A novel off-grid optimal hybrid energy system for rural electrification of Tanzania using a closed loop cooled solar system. Energies 2018;11(4). https://doi.org/10.3390/en11040905.

[141] Akhtari MR, Baneshi M. Techno-economic assessment and optimization of a hybrid renewable co-supply of electricity, heat and hydrogen system to enhance performance by recovering excess electricity for a large energy consumer. Energy Conversion and Management 2019;188:131-41. https://doi.org/10.1016/j.enconman.2019.03.067.

[142] Awan AB. Performance analysis and optimization of a hybrid renewable energy system for sustainable NEOM city in Saudi Arabia. Journal of Renewable and Sustainable Energy 2019;11(2). https://doi.org/10.1063/1.5071449.

[143] Farzaneh H. Design of a hybrid renewable energy system based on supercritical water gasification of biomass for off-grid power supply in Fukushima. Energies 2019;12(14). https://doi.org/10.3390/en12142709.

[144] Gambino V, Citto RD, Cherubini P, Tacconelli C, Micangeli A, Giglioli R. Methodology for the energy need assessment to effectively design and deploy mini-grids for rural electrification. Energies 2019;12(3). https://doi.org/10.3390/en12030574.

[145] Kaluthanthrige R, Rajapakse AD, Lamothe C, Mosallat F. Optimal Sizing and Performance Evaluation of a Hybrid Renewable Energy System for an Off-Grid Power System in Northern Canada. Technology and Economics of Smart Grids and Sustainable Energy 2019;4(1). https://doi.org/10.1007/s40866-019-0061-5.

[146] Kannengießer T, Hoffmann M, Kotzur L, Stenzel P, Schuetz F, Peters K et al. Reducing computational load for mixed integer linear programming: An example for a district and an island energy system. Energies 2019;12(14). https://doi.org/10.3390/en12142825.

[147] Muselli M, Notton G, Poggi P, Louche A. Computer-aided analysis of the integration of renewable-energy systems in remote areas using a geographical-information system. Applied Energy 1999;63(3):141-60. https://doi.org/10.1016/S0306-2619(99)00027-6.

[148] Kaldellis JK. Parametrical investigation of the wind-hydro electricity production solution for Aegean Archipelago. Energy Conversion and Management 2002;43(16):2097-113. https://doi.org/10.1016/S0196-8904(01)00168-6.

[149] Nystedt $\AA$, Shemeikka J, Klobut K. Case analyses of heat trading between buildings connected by a district heating network. Energy Conversion and Management 2006;47(20):3652-8. https://doi.org/10.1016/j.enconman.2006.02.030.

[150] Liu H-Y, Wu S-D. An assessment on the planning and construction of an island renewable energy system - A case study of Kinmen Island. Renewable Energy 2010;35(12):2723-31. https://doi.org/10.1016/j.renene.2010.04.021.

[151] Brandoni C, Polonara F. Technical and economic aspects of municipal energy planning. International Journal of Sustainable Development and Planning 2012;7(2):221-36. https://doi.org/10.2495/SDP-V7-N2-221-236.

[152] Pérez-Romero M, Lozano-Tello A, Romero-Cadaval E, Martins J. Community and residential energy storage in smart grids. IFIP Advances in Information and Communication Technology 2013;394:315-22.

[153] Vick BD, Moss TA. Adding concentrated solar power plants to wind farms to achieve a good utility electrical load match. Solar Energy 2013;92:298-312. https://doi.org/10.1016/j.solener.2013.03.007. 
[154] Raghav Chakravarthy ES, Bhargavi A, Parkavi Kathirvelu K, Balasubramanian R. Analysis and simulation of isolated wind diesel hybrid power system. ARPN Journal of Engineering and Applied Sciences 2014;9(7):1056-63.

[155] Moret S, Peduzzi E, Gerber L, Maréchal F. Integration of deep geothermal energy and woody biomass conversion pathways in urban systems. Energy Conversion and Management 2016;129:305-18. https://doi.org/10.1016/j.enconman.2016.09.079.

[156] Morvaj B, Evins R, Carmeliet J. Decarbonizing the electricity grid: The impact on urban energy systems, distribution grids and district heating potential. Applied Energy 2017;191:125-40. https://doi.org/10.1016/j.apenergy.2017.01.058.

[157] Paiho S, Hoang H, Hukkalainen M. Energy and emission analyses of solar assisted local energy solutions with seasonal heat storage in a Finnish case district. Renewable Energy 2017;107:147-55. https://doi.org/10.1016/j.renene.2017.02.003.

[158] Prasanna A, Dorer V, Vetterli N. Optimisation of a district energy system with a low temperature network. Energy 2017;137:63248. https://doi.org/10.1016/j.energy.2017.03.137.

[159] Robertson E, Galloway S. Multienergy vector modelling of a Scottish Energy System: Transitions and technology implications. Proceedings of the Institution of Mechanical Engineers, Part A: Journal of Power and Energy 2017;231(6):580-9. https://doi.org/10.1177/0957650917711820.

[160] Yazdanie M, Densing M, Wokaun A. Cost optimal urban energy systems planning in the context of national energy policies: A case study for the city of Basel. Energy Policy 2017;110:176-90. https://doi.org/10.1016/j.enpol.2017.08.009.

[161] Scheller F, Krone J, Kühne S, Bruckner T. Provoking Residential Demand Response Through Variable Electricity Tariffs - A Model-Based Assessment for Municipal Energy Utilities. Technology and Economics of Smart Grids and Sustainable Energy 2018;3(1). https://doi.org/10.1007/s40866-018-0045-x.

[162] Burton CA, Ryan C, Rismanchi B, Candy S. Urban shared energy systems and behaviour change - simulating a common pooled resource problem. Smart and Sustainable Built Environment 2019. https://doi.org/10.1108/SASBE-01-2019-0013.

[163] Perera A, Nik VM, Wickramasinghe PU, Scartezzini J-L. Redefining energy system flexibility for distributed energy system design. Applied Energy 2019;253. https://doi.org/10.1016/j.apenergy.2019.113572.

[164] Razmjoo A, Shirmohammadi R, Davarpanah A, Pourfayaz F, Aslani A. Stand-alone hybrid energy systems for remote area power generation. Energy Reports 2019;5:231-41. https://doi.org/10.1016/j.egyr.2019.01.010.

[165] Teah HS, Yang Q, Onuki M, Teah HY. Incorporating external effects into project sustainability assessments: The case of a green campus initiative based on a solar PV system. Sustainability (Switzerland) 2019;11(20). https://doi.org/10.3390/su11205786.

[166] Toboso-Chavero S, Nadal A, Petit-Boix A, Pons O, Villalba G, Gabarrell X et al. Towards Productive Cities: Environmental Assessment of the Food-Energy-Water Nexus of the Urban Roof Mosaic. Journal of Industrial Ecology 2019;23(4):767-80. https://doi.org/10.1111/jiec.12829.

[167] Weinand JM, McKenna R, Fichtner W. Developing a municipality typology for modelling decentralised energy systems. Utilities Policy 2019;57:75-96. https://doi.org/10.1016/j.jup.2019.02.003.

[168] Calvert K, Mabee W. More solar farms or more bioenergy crops? Mapping and assessing potential land-use conflicts among renewable energy technologies in eastern Ontario, Canada. Applied Geography 2015;56:209-21. https://doi.org/10.1016/j.apgeog.2014.11.028.

[169] Tucho GT, Nonhebel S. Alternative energy supply system to a rural village in Ethiopia. Energy, Sustainability and Society 2017;7(1). https://doi.org/10.1186/s13705-017-0136-x.

[170] Fan S, Li Z, Wang J, Piao L, Ai Q. Cooperative Economic Scheduling for Multiple Energy Hubs: A Bargaining Game Theoretic Perspective. IEEE Access 2018;6:27777-89. https://doi.org/10.1109/ACCESS.2018.2839108.

[171] Meschede H. Increased utilisation of renewable energies through demand response in the water supply sector - A case study. Energy 2019;175:810-7. https://doi.org/10.1016/j.energy.2019.03.137.

[172] Facchinetti E, Rohrbach B, van der Wel G, Bollinger A. Monetary value of a district's flexibility on the spotand reserve electricity markets. Buildings 2018;8(12). https://doi.org/10.3390/buildings8120181.

[173] Perera A, Coccolo S, Scartezzini J-L, Mauree D. Quantifying the impact of urban climate by extending the boundaries of urban energy system modeling. Applied Energy 2018;222:847-60. https://doi.org/10.1016/j.apenergy.2018.04.004.

[174] Gardumi F, Welsch M, Howells M, Colombo E. Representation of balancing options for variable renewables in long-term energy system models: An application to OSeMOSYS. Energies 2019;12(12). https://doi.org/10.3390/en12122366.

[175] Hirvonen J, ur Rehman H, Sirén K. Techno-economic optimization and analysis of a high latitude solar district heating system with seasonal storage, considering different community sizes. Solar Energy 2018;162:472-88. https://doi.org/10.1016/j.solener.2018.01.052.

[176] Yazdanie M, Densing M, Wokaun A. The role of decentralized generation and storage technologies in future energy systems planning for a rural agglomeration in Switzerland. Energy Policy 2016;96:432-45. https://doi.org/10.1016/j.enpol.2016.06.010.

[177] Amil M. Developing energy statistics. Comparison of galician energy balance with other autonomous regions [La elaboración de estadísticas energéticas. Comparación del balance energético gallego y de otras comunidades autónomas]. Revista Galega de Economia 2010;19(1):1-16.

[178] Regueiro Ferreira RM, Sánchez Sellero MC. Correspondences analysis application data on employment generation in the electrical system of Spain [Aplicación da análise de correspondencias sobre os datos de xeración de emprego no sistema eléctrico de España]. Revista Galega de Economia 2014;23(1):227-43.

[179] Lund H, Möller B, Mathiesen BV, Dyrelund A. The role of district heating in future renewable energy systems. Energy 2010;35(3):1381-90. https://doi.org/10.1016/j.energy.2009.11.023.

[180] Petrović S, Karlsson K. Ringkøbing-Skjern energy atlas for analysis of heat saving potentials in building stock. Energy 2016;110:166-77. https://doi.org/10.1016/j.energy.2016.04.046.

[181] Jaccard M, Murphy R, Zuehlke B, Braglewicz M. Cities and greenhouse gas reduction: Policy makers or policy takers? Energy Policy 2019;134. https://doi.org/10.1016/j.enpol.2019.07.011.

[182] Byrne J, Shen B, Wallace W. The economics of sustainable energy for rural development: A study of renewable energy in rural China. Energy Policy 1998;26(1):45-54. 
[183] Vosen SR, Keller JO. Hybrid energy storage systems for stand-alone electric power systems: Optimization of system performance and cost through control strategies. International Journal of Hydrogen Energy 1999;24(12):1139-56. https://doi.org/10.1016/S03603199(98)00175-X.

[184] Santarelli M, Macagno S. Hydrogen as an energy carrier in stand-alone applications based on PV and PV-micro-hydro systems. Energy 2004;29(8):1159-82. https://doi.org/10.1016/j.energy.2004.02.023.

[185] Khan MJ, Iqbal MT. Pre-feasibility study of stand-alone hybrid energy systems for applications in Newfoundland. Renewable Energy 2005;30(6):835-54. https://doi.org/10.1016/j.renene.2004.09.001.

[186] Obara S. Operating schedule of a combined energy network system with fuel cell. International Journal of Energy Research 2006;30(13):1055-73. https://doi.org/10.1002/er.1203.

[187] Kaldellis JK. An integrated model for performance simulation of hybrid wind-diesel systems. Renewable Energy 2007;32(9):154464. https://doi.org/10.1016/j.renene.2006.07.004.

[188] Diaf S, Notton G, Belhamel M, Haddadi M, Louche A. Design and techno-economical optimization for hybrid PV/wind system under various meteorological conditions. Applied Energy 2008;85(10):968-87. https://doi.org/10.1016/j.apenergy.2008.02.012.

[189] Palmer DJ, Sachs GD, Sembler WJ. A Solar-Hydrogen Fuel-Cell Home and research platform. Journal of Fuel Cell Science and Technology 2009;6(3):345041-6. https://doi.org/10.1115/1.3006309.

[190] Saheb-Koussa D, Haddadi M, Belhamel M. Economic and technical study of a hybrid system (wind-photovoltaic-diesel) for rural electrification in Algeria. Applied Energy 2009;86(7-8):1024-30. https://doi.org/10.1016/j.apenergy.2008.10.015.

[191] Bentouba S, Slimani A, Boucherit MS, Bourouis M, Coronas A. Analysis of photovoltaic power system in remote area in Adrar south of Algeria. International Review of Mechanical Engineering 2010;4(4):460-5.

[192] Colella WG, Schneider SH, Kammen DM, Jhunjhunwala A, Teo N. Optimizing the design and deployment of stationary combined heat and power fuel cell systems for minimum costs and emissions - Part I: Model design. Journal of Fuel Cell Science and Technology 2011;8(2). https://doi.org/10.1115/1.4001756.

[193] Colella WG, Schneider SH, Kammen DM, Jhunjhunwala A, Teo N. Optimizing the design and deployment of stationary combined heat and power fuel cell systems for minimum costs and emissions - Part II: Model results. Journal of Fuel Cell Science and Technology 2011;8(2). https://doi.org/10.1115/1.4001757.

[194] Kyriakarakos G, Dounis AI, Rozakis S, Arvanitis KG, Papadakis G. Polygeneration microgrids: A viable solution in remote areas for supplying power, potable water and hydrogen as transportation fuel. Applied Energy 2011;88(12):4517-26. https://doi.org/10.1016/j.apenergy.2011.05.038.

[195] Adaramola MS. Feasibility study of off-grid hybrid energy systems for applications in Ondo state Nigeria. Journal of Engineering and Applied Sciences 2012;7(1):72-8. https://doi.org/10.3923/jeasci.2012.72.78.

[196] Shiroudi A, Rashidi R, Gharehpetian GB, Mousavifar SA, Akbari Foroud A. Case study: Simulation and optimization of photovoltaic-wind-battery hybrid energy system in Taleghan-Iran using homer software. Journal of Renewable and Sustainable Energy 2012;4(5). https://doi.org/10.1063/1.4754440.

[197] Anayochukwu AV, Ndubueze NA. The potential of stand-alone PV/wind hybrid energy systems for power supply to remote rural areas in Nigeria. International Journal of Energy for a Clean Environment 2013;14(1):1-20. https://doi.org/10.1615/InterJEnerCleanEnv.2012004922.

[198] Rawat R, Chandel SS. Simulation and optimization of solar photovoltaic-wind stand alone hybrid system in hilly terrain of India. International Journal of Renewable Energy Research 2013;3(3):595-604.

[199] Kusakana K. Techno-economic analysis of off-grid hydrokinetic-based hybrid energy systems for onshore/remote area in South Africa. Energy 2014;68:947-57. https://doi.org/10.1016/j.energy.2014.01.100.

[200] Lacko R, Drobnič B, Mori M, Sekavčnik M, Vidmar M. Stand-alone renewable combined heat and power system with hydrogen technologies for household application. Energy 2014;77:164-70. https://doi.org/10.1016/j.energy.2014.05.110.

[201] Lacko R, Drobnič B, Sekavčnik M, Mori M. Hydrogen energy system with renewables for isolated households: The optimal system design, numerical analysis and experimental evaluation. Energy and Buildings 2014;80:106-13. https://doi.org/10.1016/j.enbuild.2014.04.009.

[202] Muda W, Fong CA, Al-Kayiem H.H. ZSBC. Simulation-based method to evaluate a PV/wind hybrid renewable energy system in Terengganu. WIT Transactions on Ecology and the Environment 2014;186:91-102. https://doi.org/10.2495/ESUS140081.

[203] Saheb D, Koussa M, Hadji S. Technical and economical study of a stand-alone wind energy system for remote rural area electrification in Algeria. Renewable Energy and Power Quality Journal 2014;1(12):638-43. https://doi.org/10.24084/repqj12.439.

[204] Yazdanpanah M-A. Modeling and sizing optimization of hybrid photovoltaic/wind power generation system. Journal of Industrial Engineering International 2014;10(1). https://doi.org/10.1007/s40092-014-0049-7.

[205] Alnejaili T, Drid S, Mehdi D, Chrifi-Alaoui L, Belarbi R, Hamdouni A. Dynamic control and advanced load management of a stand-alone hybrid renewable power system for remote housing. Energy Conversion and Management 2015;105:377-92. https://doi.org/10.1016/j.enconman.2015.07.080.

[206] Ani VA. Feasibility analysis and simulation of a stand-alone photovoltaic energy system for electricity generation and environmental sustainability - equivalent to 650VA fuel-powered generator - popularly known as "I pass my neighbour. Frontiers in Energy Research 2015;3(SEP). https://doi.org/10.3389/fenrg.2015.00038.

[207] Hong GW, Abe N, Baclay M JR., Arciaga L. Assessing users' performance to sustain off-grid renewable energy systems: The capacity and willingness approach. Energy for Sustainable Development 2015;28:102-14. https://doi.org/10.1016/j.esd.2015.07.004.

[208] Kim J-H, Kim H-R, Kim J-T. Analysis of photovoltaic applications in zero energy building cases of IEA SHC/EBC Task 40/Annex 52. Sustainability (Switzerland) 2015;7(7):8782-800. https://doi.org/10.3390/su7078782.

[209] Sharifishourabi M, Alimoradiyan H, Atikol U. Modeling of hybrid renewable energy system: The case study of Istanbul, Turkey. Journal of Thermal Engineering 2016;2(6):990-4. https://doi.org/10.18186/jte.10645. 
[210] McKenna R, Merkel E, Fichtner W. Energy autonomy in residential buildings: A techno-economic model-based analysis of the scale effects. Applied Energy 2017;189:800-15. https://doi.org/10.1016/j.apenergy.2016.03.062.

[211] Sagani A, Vrettakos G, Dedoussis V. Viability assessment of a combined hybrid electricity and heat system for remote household applications. Solar Energy 2017;151:33-47. https://doi.org/10.1016/j.solener.2017.05.011.

[212] Duman AC, Güler Ö. Techno-economic analysis of off-grid PV/wind/fuel cell hybrid system combinations with a comparison of regularly and seasonally occupied households. Sustainable Cities and Society 2018;42:107-26. https://doi.org/10.1016/j.scs.2018.06.029.

[213] Ferrari L, Bianchini A, Galli G, Ferrara G, Carnevale EA. Influence of actual component characteristics on the optimal energy mix of a photovoltaic-wind-diesel hybrid system for a remote off-grid application. Journal of Cleaner Production 2018;178:206-19. https://doi.org/10.1016/j.jclepro.2018.01.032.

[214] Maleki A. Modeling and optimum design of an off-grid PV/WT/FC/diesel hybrid system considering different fuel prices. International Journal of Low-Carbon Technologies 2018;13(2):140-7. https://doi.org/10.1093/ijlct/cty006.

[215] Rey-Hernández JM, Yousif C, Gatt D, Velasco-Gómez E, San José-Alonso J, Rey-Martínez FJ. Modelling the long-term effect of climate change on a zero energy and carbon dioxide building through energy efficiency and renewables. Energy and Buildings 2018;174:85-96. https://doi.org/10.1016/j.enbuild.2018.06.006.

[216] Franchini G, Brumana G, Perdichizzi A. Monitored performance of the first energy+ autonomous building in Dubai. Energy and Buildings 2019;205. https://doi.org/10.1016/j.enbuild.2019.109545.

[217] Leary J, Schaube P, Clementi L. Rural electrification with household wind systems in remote high wind regions. Energy for Sustainable Development 2019;52:154-75. https://doi.org/10.1016/j.esd.2019.07.008.

[218] Maouedj R, Benmedjahed M, Saba D, Mamemri A, Barbaoui B, Bezari S. Experimental analysis of a stand-alone windphotovoltaic hybrid system in the Sahara Desert. European Journal of Electrical Engineering 2019;21(1):93-7. https://doi.org/10.18280/ejee.210114.

[219] Pawale TP, Chakrasali RL, Motekar RS, Halabhavi SB. Power reliability of hybrid non-conventional off-grid generation systems using multilevel inverter. International Journal of Recent Technology and Engineering 2019;8(1):3450-5.

[220] Obara S, Watanabe S, Rengarajan B. Operation planning of an independent microgrid for cold regions by the distribution of fuel cells and water electrolyzers using a genetic algorithm. International Journal of Hydrogen Energy 2011;36(22):14295-308. https://doi.org/10.1016/j.ijhydene.2011.08.004.

[221] Shah KK, Mundada AS, Pearce JM. Performance of U.S. hybrid distributed energy systems: Solar photovoltaic, battery and combined heat and power. Energy Conversion and Management 2015;105:71-80. https://doi.org/10.1016/j.enconman.2015.07.048.

[222] Assaf J, Shabani B. A novel hybrid renewable solar energy solution for continuous heat and power supply to standalone-alone applications with ultimate reliability and cost effectiveness. Renewable Energy 2019;138:509-20. https://doi.org/10.1016/j.renene.2019.01.099.

[223] Heydari A, Askarzadeh A. Optimization of a biomass-based photovoltaic power plant for an off-grid application subject to loss of power supply probability concept. Applied Energy 2016;165:601-11. https://doi.org/10.1016/j.apenergy.2015.12.095.

[224] Khattab NM, Badr MA, El Shenawy ET, Sharawy HH, Shalaby MS. Feasibility of hybrid renewable energy water pumping system for a small farm in Egypt. International Journal of Applied Engineering Research 2016;11(11):7406-14.

[225] Habali SM, Saleh IA. Design of stand-alone brackish water desalination wind energy system for Jordan. Solar Energy 1994;52(6):525-32. https://doi.org/10.1016/0038-092X(94)90660-2.

[226] Karimi L, Abkar L, Aghajani M, Ghassemi A. Technical feasibility comparison of off-grid PV-EDR and PV-RO desalination systems via their energy consumption. Separation and Purification Technology 2015;151:82-94. https://doi.org/10.1016/j.seppur.2015.07.023.

[227] Maleki A, Khajeh MG, Rosen MA. Weather forecasting for optimization of a hybrid solar-wind-powered reverse osmosis water desalination system using a novel optimizer approach. Energy 2016;114:1120-34. https://doi.org/10.1016/j.energy.2016.06.134.

[228] Astolfi M, Mazzola S, Silva P, Macchi E. A synergic integration of desalination and solar energy systems in stand-alone microgrids. Desalination 2017;419:169-80. https://doi.org/10.1016/j.desal.2017.05.025.

[229] Kyriakarakos G, Dounis AI, Arvanitis KG, Papadakis G. Design of a Fuzzy Cognitive Maps variable-load energy management system for autonomous PV-reverse osmosis desalination systems: A simulation survey. Applied Energy 2017;187:575-84. https://doi.org/10.1016/j.apenergy.2016.11.077.

[230] Wu B, Maleki A, Pourfayaz F, Rosen MA. Optimal design of stand-alone reverse osmosis desalination driven by a photovoltaic and diesel generator hybrid system. Solar Energy 2018;163:91-103. https://doi.org/10.1016/j.solener.2018.01.016.

[231] Rezk H, Sayed ET, Al-Dhaifallah M, Obaid M, El-Sayed A, Abdelkareem MA et al. Fuel cell as an effective energy storage in reverse osmosis desalination plant powered by photovoltaic system. Energy 2019;175:423-33. https://doi.org/10.1016/j.energy.2019.02.167.

[232] McGowan JG, Manwell JF, Avelar C, Warner CL. Hybrid wind/PV/diesel hybrid power systems modeling and south American applications. Renewable Energy 1996;9(1-4 SPEC. ISS):836-47.

[233] Gómez G, Martínez G, Gálvez JL, Gila R, Cuevas R, Maellas J et al. Optimization of the photovoltaic-hydrogen supply system of a stand-alone remote-telecom application. International Journal of Hydrogen Energy 2009;34(13):5304-10. https://doi.org/10.1016/j.ijhydene.2009.05.014.

[234] Merei G, Berger C, Sauer DU. Optimization of an off-grid hybrid PV-Wind-Diesel system with different battery technologies using genetic algorithm. Solar Energy 2013;97:460-73. https://doi.org/10.1016/j.solener.2013.08.016.

[235] Alsharif MH, Nordin R, Ismail M. Energy optimisation of hybrid off-grid system for remote telecommunication base station deployment in Malaysia. Eurasip Journal on Wireless Communications and Networking 2015;2015(1):1-15. https://doi.org/10.1186/s13638-015-0284-7.

[236] Goel S, Ali SM. Hybrid energy systems for off-grid remote telecom tower in Odisha, India. International Journal of Ambient Energy 2015;36(3):116-22. https://doi.org/10.1080/01430750.2013.823110. 
[237] Olatomiwa L, Mekhilef S, Huda A, Sanusi K. Techno-economic analysis of hybrid PV-diesel-battery and PV-wind-diesel-battery power systems for mobile BTS: The way forward for rural development. Energy Science and Engineering 2015;3(4):271-85. https://doi.org/10.1002/ese3.71.

[238] Scamman D, Newborough M, Bustamante H. Hybrid hydrogen-battery systems for renewable off-grid telecom power. International Journal of Hydrogen Energy 2015;40(40):13876-87. https://doi.org/10.1016/j.ijhydene.2015.08.071.

[239] Alsharif MH, Kim J. Hybrid off-grid SPV/WTG power system for remote cellular base stations towards green and sustainable cellular networks in South Korea. Energies 2017;10(1). https://doi.org/10.3390/en10010009.

[240] Yeshalem MT, Khan B. Design of an off-grid hybrid PV/wind power system for remote mobile base station: A case study. AIMS Energy 2017;5(1):96-112. https://doi.org/10.3934/energy.2017.1.96.

[241] Alsharif MH, Kim J, Kim JH. Energy optimization strategies for Eco-friendly cellular base stations. Energies 2018;11(6). https://doi.org/10.3390/en11061500.

[242] Murugesan C, Marimuthu CN. Cost optimization of PV-Diesel Systems in Nanogrid Using L J Cuckoo Search and its Application in Mobile Towers. Mobile Netw Appl 2019;24(2):340-9. https://doi.org/10.1007/s11036-018-1046-7.

[243] El Asmar T. React: Self-sufficient renewable energy air-conditioning system for Mediterranean countries. Desalination 2008;220(13):600-11. https://doi.org/10.1016/j.desal.2007.04.061.

[244] Crossland AF, Anuta OH, Wade NS. A socio-technical approach to increasing the battery lifetime of off-grid photovoltaic systems applied to a case study in Rwanda. Renewable Energy 2015;83:30-40. https://doi.org/10.1016/j.renene.2015.04.020.

[245] Olatomiwa L, Blanchard R, Mekhilef S, Akinyele D. Hybrid renewable energy supply for rural healthcare facilities: An approach to quality healthcare delivery. Sustainable Energy Technologies and Assessments 2018;30:121-38. https://doi.org/10.1016/j.seta.2018.09.007.

[246] Babatunde OM, Adedoja OS, Babatunde DE, Denwigwe IH. Off-grid hybrid renewable energy system for rural healthcare centers: A case study in Nigeria. Energy Science and Engineering 2019;7(3):676-93. https://doi.org/10.1002/ese3.314.

[247] Raghuwanshi SS, Arya R. Design and economic analysis of a stand-alone hybrid photovoltaic energy system for remote healthcare centre. International Journal of Sustainable Engineering 2019. https://doi.org/10.1080/19397038.2019.1629674.

[248] Nfah EM, Ngundam JM. Feasibility of pico-hydro and photovoltaic hybrid power systems for remote villages in Cameroon. Renewable Energy 2009;34(6):1445-50. https://doi.org/10.1016/j.renene.2008.10.019.

[249] Aagreh Y, Al-Ghzawi A. Feasibility of utilizing renewable energy systems for a small hotel in Ajloun city, Jordan. Applied Energy 2013;103:25-31. https://doi.org/10.1016/j.apenergy.2012.10.008.

[250] Shezan S, Saidur R, Ullah KR, Hossain A, Chong WT, Julai S. Feasibility analysis of a hybrid off-grid wind-DG-battery energy system for the eco-tourism remote areas. Clean Technologies and Environmental Policy 2015;17(8):2417-30. https://doi.org/10.1007/s10098-015-0983-0.

[251] Okonkwo EC, Okwose CF, Abbasoglu S. Techno-economic analysis of the potential utilization of a hybrid PV-wind turbine system for commercial buildings in Jordan. International Journal of Renewable Energy Research 2017;7(2):908-14.

[252] Jung TY, Kim D, Moon J, Lim S. A scenario analysis of solar photovoltaic grid parity in the Maldives: The case of Malahini resort. Sustainability (Switzerland) 2018;10(11). https://doi.org/10.3390/su10114045.

[253] Galvão JR, Moreira L, Gaspar G, Vindeirinho S, Leitão S. Energy system retrofit in a public services building. Management of Environmental Quality: An International Journal 2017;28(3):302-14. https://doi.org/10.1108/MEQ-02-2014-0028.

[254] Li N, Liu C, Li Y. Research on a long-duration solar-powered wireless sensor node energy system. Gaojishu Tongxin/Chinese High Technology Letters 2010;20(11):1201-5. https://doi.org/10.3772/j.issn.1002-0470.2010.11.018.

[255] Karakoulidis K, Mavridis K, Bandekas DV, Adoniadis P, Potolias C, Vordos N. Techno-economic analysis of a stand-alone hybrid photovoltaic-diesel-battery-fuel cell power system. Renewable Energy 2011;36(8):2238-44. https://doi.org/10.1016/j.renene.2010.12.003.

[256] McHenry MP. Small-scale ( $\leq 6 \mathrm{kWe}$ ) stand-alone and grid-connected photovoltaic, wind, hydroelectric, biodiesel, and wood gasification system's simulated technical, economic, and mitigation analyses for rural regions in Western Australia. Renewable Energy 2012;38(1):195-205. https://doi.org/10.1016/j.renene.2011.07.032.

[257] Carroquino J, Dufo-López R, Bernal-Agustín JL. Sizing of off-grid renewable energy systems for drip irrigation in Mediterranean crops. Renewable Energy 2015;76:566-74. https://doi.org/10.1016/j.renene.2014.11.069.

[258] Mudasser M, Yiridoe EK, Corscadden K. Cost-benefit analysis of grid-connected wind-biogas hybrid energy production, by turbine capacity and site. Renewable Energy 2015;80:573-82. https://doi.org/10.1016/j.renene.2015.02.055.

[259] Boussetta M, Elbachtiri R, Elhammoumi K, Khanfara M. Optimal sizing of grid-connected PV-Wind system case study: Agricultural farm in Morocco. Journal of Theoretical and Applied Information Technology 2016;86(2):196-206.

[260] Nacer T, Hamidat A, Nadjemi O. A comprehensive method to assess the feasibility of renewable energy on Algerian dairy farms. Journal of Cleaner Production 2016;112:3631-42. https://doi.org/10.1016/j.jclepro.2015.06.101.

[261] Sebbagh T, Kelaiaia R, Zaatri A, Bechara T, Abdelouahed L. Investigation of the use of a central unique renewable energy system versus distributed units for crop irrigation. Clean Technologies and Environmental Policy 2018;20(10):2365-73. https://doi.org/10.1007/s10098-018-1599-y.

[262] Anayochukwu AV, Onyeka AE. Feasibility study and simulation of optimal power system for off-grid voter registration centres. International Journal of Renewable Energy Research 2014;4(3):647-54.

[263] Keshtkaran E, Fardoun AA, Noura H. Employing hydrogen fuel cell in hybrid energy systems for stand-alone, off-grid remote sites in UAE. Renewable Energy and Power Quality Journal 2014;1(12):811-7. https://doi.org/10.24084/repqj12.499.

[264] Nizetic S, Coko D, Marasovic I. Experimental study on a hybrid energy system with small- and medium-scale applications for mild climates. Energy 2014;75:379-89. https://doi.org/10.1016/j.energy.2014.07.087.

[265] Ye B, Jiang J, Miao L, Yang P, Li J, Shen B. Feasibility study of a solar-powered electric vehicle charging station model. Energies 2015;8(11):13265-83. https://doi.org/10.3390/en81112368. 
[266] Amusat OO, Shearing PR, Fraga ES. Optimal integrated energy systems design incorporating variable renewable energy sources. Computers and Chemical Engineering 2016;95:21-37. https://doi.org/10.1016/j.compchemeng.2016.08.007.

[267] Ansong M, Mensah LD, Adaramola MS. Techno-economic analysis of a hybrid system to power a mine in an off-grid area in Ghana. Sustainable Energy Technologies and Assessments 2017;23:48-56. https://doi.org/10.1016/j.seta.2017.09.001.

[268] Amusat OO, Shearing PR, Fraga ES. Optimal design of hybrid energy systems incorporating stochastic renewable resources fluctuations. Journal of Energy Storage 2018;15:379-99. https://doi.org/10.1016/j.est.2017.12.003.

[269] Diab F, Lan H, Zhang L, Ali S. An environmentally friendly factory in Egypt based on hybrid photovoltaic/wind/diesel/battery system. Journal of Cleaner Production 2016;112:3884-94. https://doi.org/10.1016/j.jclepro.2015.07.008.

[270] Fabrizio E, Branciforti V, Costantino A, Filippi M, Barbero S, Tecco G et al. Monitoring and managing of a micro-smart grid for renewable sources exploitation in an agro-industrial site. Sustainable Cities and Society 2017;28:88-100. https://doi.org/10.1016/j.scs.2016.08.026.

[271] Roth A, Boix M, Gerbaud V, Montastruc L, Etur P. A flexible metamodel architecture for optimal design of Hybrid Renewable Energy Systems (HRES) - Case study of a stand-alone HRES for a factory in tropical island. Journal of Cleaner Production 2019;223:214-25. https://doi.org/10.1016/j.jclepro.2019.03.095.

[272] Khosravi A, Koury R, Machado L, Pabon J. Energy, exergy and economic analysis of a hybrid renewable energy with hydrogen storage system. Energy 2018;148:1087-102. https://doi.org/10.1016/j.energy.2018.02.008.

[273] Duman AC, Güler Ö. Techno-economic analysis of off-grid photovoltaic LED road lighting systems: A case study for northern, central and southern regions of Turkey. Building and Environment 2019;156:89-98. https://doi.org/10.1016/j.buildenv.2019.04.005.

[274] Diemuodeke EO, Oko C. Optimum configuration and design of a photovoltaic-diesel-battery hybrid energy system for a facility in University of Port Harcourt, Nigeria. International Journal of Ambient Energy 2016;37(1):2-9. https://doi.org/10.1080/01430750.2013.866906.

[275] Kumar A, Biswas A. Techno-economic optimization of a stand-alone photovoltaic-battery renewable energy system for low load factor situation- a comparison between optimization algorithms. International Journal of Engineering, Transactions A: Basics 2017;30(10):1555-64. https://doi.org/10.5829/ije.2017.30.10a.17.

[276] Aziz AS, Tajuddin M, Adzman M. Feasibility analysis of PV/Wind/Battery hybrid power generation: A case study. International Journal of Renewable Energy Research 2018;8(2):661-71.

[277] Salisu S, Mustafa MW, Mohammed OO, Mustapha M, Jumani TA. Techno-economic feasibility analysis of an offgrid hybrid energy system for rural electrification in Nigeria. International Journal of Renewable Energy Research 2019;9(1):261-70.

[278] Goel S, Sharma R. Feasibility study of hybrid energy system for off-grid rural water supply and sanitation system in Odisha, India. International Journal of Ambient Energy 2016;37(3):314-20. https://doi.org/10.1080/01430750.2014.962089.

[279] Di Fraia S, Macaluso A, Massarotti N, Vanoli L. Energy, exergy and economic analysis of a novel geothermal energy system for wastewater and sludge treatment. Energy Conversion and Management 2019;195:533-47. https://doi.org/10.1016/j.enconman.2019.05.035.

[280] Haas J, Cebulla F, Nowak W, Rahmann C, Palma-Behnke R. A multi-service approach for planning the optimal mix of energy storage technologies in a fully-renewable power supply. Energy Conversion and Management 2018;178:355-68. https://doi.org/10.1016/j.enconman.2018.09.087.

[281] Waite M, Modi V. Impact of deep wind power penetration on variability at load centers. Applied Energy 2019;235:1048-60. https://doi.org/10.1016/j.apenergy.2018.11.021.

[282] Kasperowicz R, Pinczyński M, Khabdullin A. Modeling the power of renewable energy sources in the context of classical electricity system transformation. Journal of International Studies 2017;10(3):264-72. https://doi.org/10.14254/2071-8330.2017/10$3 / 19$.

[283] Karlsson K, Meibom P. Optimal investment paths for future renewable based energy systems-Using the optimisation model Balmorel. International Journal of Hydrogen Energy 2008;33(7):1777-87. https://doi.org/10.1016/j.ijhydene.2008.01.031.

[284] Vaillancourt K, Labriet M, Loulou R, Waaub J-P. The role of nuclear energy in long-term climate scenarios: An analysis with the World-TIMES model. Energy Policy 2008;36(7):2296-307. https://doi.org/10.1016/j.enpol.2008.01.015.

[285] Goodbody C, Walsh E, McDonnell KP, Owende P. Regional integration of renewable energy systems in Ireland - The role of hybrid energy systems for small communities. International Journal of Electrical Power and Energy Systems 2013;44(1):713-20. https://doi.org/10.1016/j.ijepes.2012.08.012.

[286] Breyer C, Bogdanov D, Komoto K, Ehara T, Song J, Enebish N. North-East Asian Super Grid: Renewable energy mix and economics. Japanese Journal of Applied Physics 2015;54(8). https://doi.org/10.7567/JJAP.54.08KJ01.

[287] Bogdanov D, Breyer C. North-East Asian Super Grid for 100\% renewable energy supply: Optimal mix of energy technologies for electricity, gas and heat supply options. Energy Conversion and Management 2016;112:176-90. https://doi.org/10.1016/j.enconman.2016.01.019.

[288] Dominković DF, Bačeković I, Ćosić B, Krajačić G, Pukšec T, Duić N et al. Zero carbon energy system of South East Europe in 2050. Applied Energy 2016;184:1517-28. https://doi.org/10.1016/j.apenergy.2016.03.046.

[289] Frew BA, Becker S, Dvorak MJ, Andresen GB, Jacobson MZ. Flexibility mechanisms and pathways to a highly renewable US electricity future. Energy 2016;101:65-78. https://doi.org/10.1016/j.energy.2016.01.079.

[290] Aghahosseini A, Bogdanov D, Breyer C. A techno-economic study of an entirely renewable energy-based power supply for North America for 2030 conditions. Energies 2017;10(8). https://doi.org/10.3390/en10081171.

[291] Breyer C, Bogdanov D, Gulagi A, Aghahosseini A, Barbosa L, Koskinen O et al. On the role of solar photovoltaics in global energy transition scenarios. Progress in Photovoltaics: Research and Applications 2017;25(8):727-45. https://doi.org/10.1002/pip.2885.

[292] Gulagi A, Bogdanov D, Breyer C. A cost optimized fully sustainable power system for Southeast Asia and the Pacific Rim. Energies 2017;10(5). https://doi.org/10.3390/en10050583. 
[293] Gulagi A, Bogdanov D, Fasihi M, Breyer C. Can Australia power the energy-hungry asia with renewable energy? Sustainability (Switzerland) 2017;9(2). https://doi.org/10.3390/su9020233.

[294] Gulagi A, Choudhary P, Bogdanov D, Breyer C. Electricity system based on 100\% renewable energy for India and SAARC. PLoS ONE 2017;12(7). https://doi.org/10.1371/journal.pone.0180611.

[295] Hess D, Wetzel M, Cao K-K. Representing node-internal transmission and distribution grids in energy system models. Renewable Energy 2018;119:874-90. https://doi.org/10.1016/j.renene.2017.10.041.

[296] Ikäheimo J, Kiviluoma J, Weiss R, Holttinen H. Power-to-ammonia in future North European $100 \%$ renewable power and heat system. International Journal of Hydrogen Energy 2018;43(36):17295-308. https://doi.org/10.1016/j.ijhydene.2018.06.121.

[297] Oyewo AS, Aghahosseini A, Bogdanov D, Breyer C. Pathways to a fully sustainable electricity supply for Nigeria in the mid-term future. Energy Conversion and Management 2018;178:44-64. https://doi.org/10.1016/j.enconman.2018.10.036.

[298] Bogdanov D, Farfan J, Sadovskaia K, Aghahosseini A, Child M, Gulagi A et al. Radical transformation pathway towards sustainable electricity via evolutionary steps. Nature Communications 2019;10(1). https://doi.org/10.1038/s41467-019-08855-1.

[299] Bogdanov D, Toktarova A, Breyer C. Transition towards 100\% renewable power and heat supply for energy intensive economies and severe continental climate conditions: Case for Kazakhstan. Applied Energy 2019;253. https://doi.org/10.1016/j.apenergy.2019.113606.

[300] Breyer C, Fasihi M, Aghahosseini A. Carbon dioxide direct air capture for effective climate change mitigation based on renewable electricity: A new type of energy system sector coupling. Mitigation and Adaptation Strategies for Global Change 2019. https://doi.org/10.1007/s11027-019-9847-y.

[301] Breyer C, Khalili S, Bogdanov D. Solar photovoltaic capacity demand for a sustainable transport sector to fulfil the Paris Agreement by 2050. Progress in Photovoltaics: Research and Applications 2019;27(11):978-89. https://doi.org/10.1002/pip.3114.

[302] Child M, Kemfert C, Bogdanov D, Breyer C. Flexible electricity generation, grid exchange and storage for the transition to a $100 \%$ renewable energy system in Europe. Renewable Energy 2019;139:80-101. https://doi.org/10.1016/j.renene.2019.02.077.

[303] Moner-Girona M, Bódis K, Morrissey J, Kougias I, Hankins M, Huld T et al. Decentralized rural electrification in Kenya: Speeding up universal energy access. Energy for Sustainable Development 2019;52:128-46. https://doi.org/10.1016/j.esd.2019.07.009.

[304] Vanhanen JP, Kauranen PS, Lund PD, Manninen LM. Simulation of solar hydrogen energy systems. Solar Energy 1994;53(3):26778. https://doi.org/10.1016/0038-092X(94)90633-5.

[305] Notton G, Muselli M, Poggi P, Louche A. Decentralized wind energy systems providing small electrical loads in remote areas. International Journal of Energy Research 2001;25(2):141-64. https://doi.org/10.1002/er.670.

[306] Tsoutsos TD, Zoulias EI, Lymberopoulos N, Glöckner R. Analysis of the barriers for the hydrogen energy technology in standalone power systems. Wind Engineering 2004;28(5):615-20. https://doi.org/10.1260/0309524043028055.

[307] Khan MJ, Iqbal MT. Dynamic modeling and simulation of a small wind-fuel cell hybrid energy system. Renewable Energy 2005;30(3):421-39. https://doi.org/10.1016/j.renene.2004.05.013.

[308] McKeough P, Solantausta Y, Kyllönen H, Faaij A, Hamelinck C, Wagener M et al. Techno-economic analysis of biotrade chains. Upgraded biofuels from Russia and Canada to the Netherlands. VTT Tiedotteita - Valtion Teknillinen Tutkimuskeskus 2005(2312):3-40.

[309] Hrayshat ES. Wind resource assessment of the Jordanian southern region. Renewable Energy 2007;32(11):1948-60. https://doi.org/10.1016/j.renene.2006.11.008.

[310] Matsunaka M, Shido S, Kondo K, Miyamaru H, Murata I. Burnup calculation of fusion-fission hybrid energy system with thorium cycle. Fusion Engineering and Design 2007;82(15-24):2779-85. https://doi.org/10.1016/j.fusengdes.2007.03.047.

[311] Aghajani S, Joneidi IA, Kalantar M, Mortezapour V. Modeling and simulation of a PV/FC/UC hybrid energy system for stand alone applications. International Review on Modelling and Simulations 2010;3(1):82-9.

[312] Hammar L, Ehnberg J, Mavume A, Francisco F, Molander S. Simplified site-screening method for micro tidal current turbines applied in Mozambique. Renewable Energy 2012;44:414-22. https://doi.org/10.1016/j.renene.2012.02.010.

[313] Jain S, Jiang J, Huang X, Stevandic S. Modeling of fuel-cell-based power supply system for grid interface. IEEE Transactions on Industry Applications 2012;48(4):1142-53. https://doi.org/10.1109/TIA.2012.2199454.

[314] Moussa MF, Dessouky YG, Hakansson A. JLHMHR. Design and control of a diode clamped multilevel wind energy system using a stand-alone AC-DC-AC converter. Smart Innovation, Systems and Technologies 2013;22:797-812. https://doi.org/10.1007/9783-642-36645-1_71.

[315] Gehring D. Wave catcher provides momentum for alternative energy. Sea Technology 2014;55(8):41-7.

[316] Jahangiri M, Nematollahi O, Sedaghat A, Saghafian M. Techno-economical assessment of renewable energies integrated with fuel cell for off grid electrification: A case study for developing countries. Journal of Renewable and Sustainable Energy 2015;7(2). https://doi.org/10.1063/1.4918592.

[317] Manfrida G, Secchi R. Performance prediction of a Small-Size Adiabatic Compressed-Air Energy Storage system. International Journal of Thermodynamics 2015;18(2):111-9. https://doi.org/10.5541/ijot.5000071710.

[318] Stockley T, Thanapalan K, Bowkett M, Williams J. Enhanced OCV prediction mechanism for a stand-alone PV-lithium ion renewable energy system. Systems Science and Control Engineering 2015;3(1):524-34. https://doi.org/10.1080/21642583.2015.1111780.

[319] Ursu V, Bartha S. Wind conditions modeling for small wind turbines. UPB Scientific Bulletin, Series C: Electrical Engineering and Computer Science 2015;77(2):277-88.

[320] Aissou R, Rekioua T, Rekioua D, Tounzi A. Application of nonlinear predictive control for charging the battery using wind energy with permanent magnet synchronous generator. International Journal of Hydrogen Energy 2016;41(45):20964-73. https://doi.org/10.1016/j.ijhydene.2016.05.249.

[321] Parkhurst KM, Saffron CM, Miller RO. An energy analysis comparing biomass torrefaction in depots to wind with natural gas combustion for electricity generation. Applied Energy 2016;179:171-81. https://doi.org/10.1016/j.apenergy.2016.05.121. 
[322] Barberis S, Roncallo F, Traverso A. Towards innovative district energy management: A case study with stochastic renewable generators. Entrepreneurship and Sustainability Issues 2017;4(3):294-309. https://doi.org/10.9770/jesi.2017.4.3S(5).

[323] Bordin C, Anuta HO, Crossland A, Gutierrez IL, Dent CJ, Vigo D. A linear programming approach for battery degradation analysis and optimization in offgrid power systems with solar energy integration. Renewable Energy 2017;101:417-30. https://doi.org/10.1016/j.renene.2016.08.066.

[324] Oliveira Costa Souza Rosa C de, Costa KA, da Silva Christo E, Bertahone PB. Complementarity of hydro, photovoltaic, and wind power in Rio de Janeiro State. Sustainability (Switzerland) 2017;9(7). https://doi.org/10.3390/su9071130.

[325] Parra D, Norman SA, Walker GS, Gillott M. Optimum community energy storage for renewable energy and demand load management. Applied Energy 2017;200:358-69. https://doi.org/10.1016/j.apenergy.2017.05.048.

[326] Schweiger G, Larsson P-O, Magnusson F, Lauenburg P, Velut S. District heating and cooling systems - Framework for Modelicabased simulation and dynamic optimization. Energy 2017;137:566-78. https://doi.org/10.1016/j.energy.2017.05.115.

[327] Amiri S, Weinberger G. Increased cogeneration of renewable electricity through energy cooperation in a Swedish district heating system - A case study. Renewable Energy 2018;116:866-77. https://doi.org/10.1016/j.renene.2017.10.003.

[328] Astaneh M, Dufo-López R, Roshandel R, Golzar F, Bernal-Agustín JL. A computationally efficient Li-ion electrochemical battery model for long-term analysis of stand-alone renewable energy systems. Journal of Energy Storage 2018;17:93-101. https://doi.org/10.1016/j.est.2018.02.015.

[329] Khraiwish Dalabeeh AS. Optimizing the combinations of sites, turbine types and cells types of a hybrid power system for remote sites in Jordan. Journal of Engineering and Applied Sciences 2018;13(16):6659-67. https://doi.org/10.3923/jeasci.2018.6659.6667.

[330] Li X, Chalvatzis KJ, Stephanides P. Innovative energy islands: Life-cycle cost-benefit analysis for battery energy storage. Sustainability (Switzerland) 2018;10(10). https://doi.org/10.3390/su10103371.

[331] Sanni M. Mapping dynamics of low-carbon energy innovation for small hydropower technology in Nigeria. African Journal of Science, Technology, Innovation and Development 2018;10(5):569-78. https://doi.org/10.1080/20421338.2017.1380587.

[332] Almeshaiei E, Al-Habaibeh A, Shakmak B. Rapid evaluation of micro-scale photovoltaic solar energy systems using empirical methods combined with deep learning neural networks to support systems' manufacturers. Journal of Cleaner Production 2019. https://doi.org/10.1016/j.jclepro.2019.118788.

[333] Gan LK, Echenique Subiabre E. A realistic laboratory development of an isolated wind-battery system. Renewable Energy 2019;136:645-56. https://doi.org/10.1016/j.renene.2019.01.024.

[334] Gbadegesin AO, Sun Y, Nwulu NI. Techno-economic analysis of storage degradation effect on levelised cost of hybrid energy storage systems. Sustainable Energy Technologies and Assessments 2019;36. https://doi.org/10.1016/j.seta.2019.100536.

[335] Ghorbanzadeh M, Astaneh M, Golzar F. Long-term degradation based analysis for lithium-ion batteries in off-grid wind-battery renewable energy systems. Energy 2019;166:1194-206. https://doi.org/10.1016/j.energy.2018.10.120.

[336] Nedjalkov A, Meyer J, Göken H, Reimer MV, Schade W. Blueprint and implementation of rural stand-alone power grids with second-life lithium ion vehicle traction battery systems for resilient energy supply of tropical or remote regions. Materials 2019;12(16). https://doi.org/10.3390/ma12162642.

[337] Tong K, Fang A, Yu H, Li Y, Shi L, Wang Y et al. Estimating the potential for industrial waste heat reutilization in urban district energy systems: Method development and implementation in two Chinese provinces. Environmental Research Letters 2017;12(12). https://doi.org/10.1088/1748-9326/aa8a17.

[338] Ma T, Yang H, Lu L. Feasibility study and economic analysis of pumped hydro storage and battery storage for a renewable energy powered island. Energy Conversion and Management 2014;79:387-97. https://doi.org/10.1016/j.enconman.2013.12.047.

[339] Muñoz JR, Spakovsky MR von. Decomposition in energy system synthesis/design optimization for stationary and aerospace applications. Journal of Aircraft 2003;40(1):35-42.

[340] Tan D, Baxter D, Foroozan S, Crane S. A First Resilient DC-Dominated Microgrid for Mission-Critical Space Applications. IEEE Journal of Emerging and Selected Topics in Power Electronics 2016;4(4):1147-57. https://doi.org/10.1109/JESTPE.2016.2615763.

[341] Eitzen ZA, Xu K-M, Wong T. Statistical analyses of satellite cloud object data from CERES. Part V: Relationships between physical properties of marine boundary layer clouds. Journal of Climate 2008;21(24):6668-88. https://doi.org/10.1175/2008JCLI2307.1.

[342] Fasullo JT, Trenberth KE. The annual cycle of the energy budget. Part I: Global mean and land-ocean exchanges. Journal of Climate 2008;21(10):2297-312. https://doi.org/10.1175/2007JCLI1935.1.

[343] Fasullo JT, Trenberth KE. The annual cycle of the energy budget. Part II: Meridional structures and poleward transports. Journal of Climate 2008;21(10):2313-25. https://doi.org/10.1175/2007JCLI1936.1.

[344] Chatziagorakis P, Ziogou C, Elmasides C, Sirakoulis GC, Karafyllidis I, Andreadis I et al. Enhancement of hybrid renewable energy systems control with neural networks applied to weather forecasting: The case of Olvio. Neural Computing and Applications 2016;27(5):1093-118. https://doi.org/10.1007/s00521-015-2175-6.

[345] Fargli HM, Fahmy FH, El-Sayed M. Artificial intelligence techniques for controlling pv-wind powered rural zone in Egypt. Renewable Energy and Power Quality Journal 2009;1(7):102-10. https://doi.org/10.24084/repqj07.257.

[346] Sabari Nathan L, Ashok Kumar L, Vaikundaselvan B, Ravi Krishna S. Modeling of control and power management of a hybrid wind-solar system using optimization technique. International Review on Modelling and Simulations 2013;6(5):1570-80.

[347] Malla SG, Bhende CN. Voltage control of stand-alone wind and solar energy system. International Journal of Electrical Power and Energy Systems 2014;56:361-73. https://doi.org/10.1016/j.ijepes.2013.11.030.

[348] Bogaraj T, Kanakaraj J, Chelladurai J. Modeling and simulation of stand-alone hybrid power system with fuzzy MPPT for remote load application. Archives of Electrical Engineering 2015;64(3):487-504. https://doi.org/10.2478/aee-2015-0037.

[349] Prakash SL, Arutchelvi M, Jesudaiyan AS. Autonomous PV-Array Excited Wind-Driven Induction Generator for Off-Grid Application in India. IEEE Journal of Emerging and Selected Topics in Power Electronics 2016;4(4):1259-69. https://doi.org/10.1109/JESTPE.2016.2579678. 
[350] Prinsloo G, Mammoli A, Dobson R. Discrete cogeneration optimization with storage capacity decision support for dynamic hybrid solar combined heat and power systems in isolated rural villages. Energy 2016;116:1051-64. https://doi.org/10.1016/j.energy.2016.10.026.

[351] Islar M, Brogaard S, Lemberg-Pedersen M. Feasibility of energy justice: Exploring national and local efforts for energy development in Nepal. Energy Policy 2017;105:668-76. https://doi.org/10.1016/j.enpol.2017.03.004.

[352] Prinsloo G, Mammoli A, Dobson R. Customer domain supply and load coordination: A case for smart villages and transactive control in rural off-grid microgrids. Energy 2017;135:430-41. https://doi.org/10.1016/j.energy.2017.06.106.

[353] Roumila Z, Rekioua D, Rekioua T. Energy management based fuzzy logic controller of hybrid system wind/photovoltaic/diesel with storage battery. International Journal of Hydrogen Energy 2017;42(30):19525-35. https://doi.org/10.1016/j.ijhydene.2017.06.006.

[354] Prinsloo G, Dobson R, Mammoli A. Synthesis of an intelligent rural village microgrid control strategy based on smartgrid multiagent modelling and transactive energy management principles. Energy 2018;147:263-78. https://doi.org/10.1016/j.energy.2018.01.056.

[355] Zaibi M, Champenois G, Roboam X, Belhadj J, Sareni B. Smart power management of a hybrid photovoltaic/wind stand-alone system coupling battery storage and hydraulic network. Mathematics and Computers in Simulation 2018;146:210-28. https://doi.org/10.1016/j.matcom.2016.08.009.

[356] Mosaad MI, Abed El-Raouf MO, Al-Ahmar MA, Bendary FM. Optimal PI controller of DVR to enhance the performance of hybrid power system feeding a remote area in Egypt. Sustainable Cities and Society 2019;47. https://doi.org/10.1016/j.scs.2019.101469.

[357] Swart AJ. Cost-effective remote energy monitoring using the ESP8266 NodeMCU. International Journal of Recent Technology and Engineering 2019;7(6):974-9.

[358] Alhamwi A, Medjroubi W, Vogt T, Agert C. GIS-based urban energy systems models and tools: Introducing a model for the optimisation of flexibilisation technologies in urban areas. Applied Energy 2017;191:1-9. https://doi.org/10.1016/j.apenergy.2017.01.048.

[359] Alhamwi A, Medjroubi W, Vogt T, Agert C. Modelling urban energy requirements using open source data and models. Applied Energy 2018;231:1100-8. https://doi.org/10.1016/j.apenergy.2018.09.164.

[360] Böckl B, Greiml M, Leitner L, Pichler P, Kriechbaum L, Kienberger T. HyFloW—A hybrid load flow-modelling framework to evaluate the effects of energy storage and sector coupling on the electrical load flows. Energies 2019;12(5). https://doi.org/10.3390/en12050956.

[361] Prinsloo GJ. Scoping exercise to determine load profile archetype reference shapes for solar co-generation models in isolated offgrid rural African villages. J. energy South. Afr. 2016;27(3):11. https://doi.org/10.17159/2413-3051/2016/v27i3a1375.

[362] Lombardi F, Balderrama S, Quoilin S, Colombo E. Generating high-resolution multi-energy load profiles for remote areas with an open-source stochastic model. Energy 2019;177:433-44. https://doi.org/10.1016/j.energy.2019.04.097.

[363] Das A, Balakrishnan V. Grid-connectivity of remote isolated islands-A proposition in Indian context. Journal of Renewable and Sustainable Energy 2012;4(4). https://doi.org/10.1063/1.4738591.

[364] Hauber J, Ruppert-Winkel C. Moving towards energy self-sufficiency based on renewables: Comparative case studies on the emergence of regional processes of socio-technical change in germany. Sustainability (Switzerland) 2012;4(4):491-530. https://doi.org/10.3390/su4040491.

[365] Späth P. Understanding the social dynamics of energy regions-the importance of discourse analysis. Sustainability (Switzerland) 2012;4(6):1256-73. https://doi.org/10.3390/su4061256.

[366] Bourennani F, Rahnamayan S, Naterer GF. Optimal design methods for hybrid renewable energy systems. International Journal of Green Energy 2015;12(2):148-59. https://doi.org/10.1080/15435075.2014.888999.

[367] Hecher M, Vilsmaier U, Akhavan R, Binder CR. An integrative analysis of energy transitions in energy regions: A case study of ökoEnergieland in Austria. Ecological Economics 2016;121:40-53. https://doi.org/10.1016/j.ecolecon.2015.11.015.

[368] Moss T, Francesch-Huidobro M. Realigning the electric city. Legacies of energy autarky in Berlin and Hong Kong. Energy Research and Social Science 2016;11:225-36. https://doi.org/10.1016/j.erss.2015.10.002.

[369] Good N, Martínez Ceseña EA, Mancarella P. Ten questions concerning smart districts. Building and Environment 2017;118:36276. https://doi.org/10.1016/j.buildenv.2017.03.037.

[370] Mikkola M, Jussila A, Ryynänen T. Collaboration in regional energy-efficiency development. Green Energy and Technology 2017:55-66. https://doi.org/10.1007/978-3-319-44899-2_4.

[371] Young J, Brans M. Analysis of factors affecting a shift in a local energy system towards $100 \%$ renewable energy community. Journal of Cleaner Production 2017;169:117-24. https://doi.org/10.1016/j.jclepro.2017.08.023.

[372] Katre A, Tozzi A. Assessing the sustainability of decentralized renewable energy systems: A comprehensive framework with analytical methods. Sustainability (Switzerland) 2018;10(4). https://doi.org/10.3390/su10041058.

[373] Sareen S, Baillie D, Kleinwächter J. Transitions to future energy systems: Learning from a community test field. Sustainability (Switzerland) 2018;10(12). https://doi.org/10.3390/su10124513.

[374] Bertheau P, Dionisio J, Jütte C, Aquino C. Challenges for implementing renewable energy in a cooperative-driven off-grid system in the Philippines. Environmental Innovation and Societal Transitions 2019. https://doi.org/10.1016/j.eist.2019.03.002.

[375] Heikkurinen P, Lozanoska J, Tosi P. Activities of degrowth and political change. Journal of Cleaner Production 2019;211:555-65. https://doi.org/10.1016/j.jclepro.2018.11.119.

[376] Kalkbrenner BJ. Residential vs. community battery storage systems - Consumer preferences in Germany. Energy Policy 2019;129:1355-63. https://doi.org/10.1016/j.enpol.2019.03.041.

[377] Mazzone A. Decentralised energy systems and sustainable livelihoods, what are the links? Evidence from two isolated villages of the Brazilian Amazon. Energy and Buildings 2019;186:138-46. https://doi.org/10.1016/j.enbuild.2019.01.027.

[378] Østergaard PA. Comparing electricity, heat and biogas storages' impacts on renewable energy integration. Energy 2012;37(1):25562. https://doi.org/10.1016/j.energy.2011.11.039. 
[379] Akizu O, Bueno G, Barcena I, Kurt E, Topaloğlu N, Lopez-Guede JM. Contributions of bottom-up energy transitions in Germany: A case study analysis. Energies 2018;11(4). https://doi.org/10.3390/en11040849.

[380] Kim K, Kim J. The optimal design and economic evaluation of a stand-alone RES energy system for residential, agricultural and commercial sectors. Korean Chemical Engineering Research 2016;54(4):470-8. https://doi.org/10.9713/kcer.2016.54.4.470.

[381] Lee D, Han S, Kim J. Economic and environmental assessment of a renewable stand-alone energy supply system using multiobjective optimization. Korean Chemical Engineering Research 2017;55(3):332-40. https://doi.org/10.9713/kcer.2017.55.3.332.

[382] Braun M, Girma Z. Techno economic assessment and optimization study of hybrid power system using homer software for electrification of rural district in Ethiopia. International Journal of Renewable Energy Research 2013;3(3):627-39.

[383] HOMER Energy. HOMER Pro: Simulation, Optimization, and Sensitivity Analysis. [October 23, 2019]; Available from: https://www.homerenergy.com/products/pro/docs/latest/solving_problems_with_homer.html.

[384] The World Bank. World Bank Country and Lending Groups. [October 28, 2019]; Available from: https://datahelpdesk.worldbank.org/knowledgebase/articles/906519-world-bank-country-and-lending-groups.

[385] Department of Development and Planning. Introduction: Introduction to EnergyPLAN. [October 25, 2019]; Available from: https://www.energyplan.eu/training/introduction/.

[386] Walker M. HOMER Optimizer ${ }^{\mathrm{TM}}$, a Faster Path to Finding Least-Cost Microgrid Options. [January 15, 2019]; Available from: https://microgridnews.com/homer-optimizer-a-faster-path-to-finding-least-cost-microgrid-options/.

[387] Reiner Lemoine Institut. Vergleich und Optimierung von zentral und dezentral orientierten Ausbaupfaden zu einer Stromversorgung aus Erneuerbaren Energien in Deutschland. [October 31, 2019]; Available from: https://www.bvmw.de/fileadmin/pdf-archiv/Studie_zur_dezentralen_Energiewende.pdf.pdf.

[388] Shivakumar A, Welsch M, Taliotis C, Jakšić D, Baričević T, Howells M et al. Valuing blackouts and lost leisure: Estimating electricity interruption costs for households across the European Union. Energy Research \& Social Science 2017;34:39-48. https://doi.org/10.1016/j.erss.2017.05.010.

[389] Limberger J, Boxem T, Pluymaekers M, Bruhn D, Manzella A, Calcagno P et al. Geothermal energy in deep aquifers: A global assessment of the resource base for direct heat utilization. Renewable and Sustainable Energy Reviews 2018;82:961-75. https://doi.org/10.1016/j.rser.2017.09.084.

[390] IEEE. Distribution Test Feeders. [January 29, 2020]; Available from: https://site.ieee.org/pes-testfeeders/.

[391] Eglitis L. WorldData. [January 08, 2020]; Available from: https://www.worlddata.info/.

[392] Reserve Bank of India. Exchange Rate of the Indian Rupee vis-à-vis the Sdr, US Dollar, Pound Sterling, D.M./Euro and Japanese Yen (Financial Year-Annual Average and end-Year Rates). [January 08, 2020]; Available from: https://www.rbi.org.in/Scripts/PublicationsView.aspx?id=19131.

[393] Statista. Euro (EUR) to British pound sterling (GBP) average annual exchange rate from 1999 to 2019. [January 08, 2020]; Available from: https://www.statista.com/statistics/412806/euro-to-gbp-average-annual-exchange-rate/.

[394] PoundSterling. The Canadian Dollar to U.S. Dollar Historical Exchange Rates Conversion Page for 2019. [January 08, 2020]; Available from: https://www.poundsterlinglive.com/best-exchange-rates/best-canadian-dollar-to-us-dollar-history-2019.

[395] GlobalPetrolPrices. Electricity prices. [January 13, 2020]; Available from: https://www.globalpetrolprices.com/electricity_prices/.

[396] Kotzur L, Markewitz P, Robinius M, Stolten D. Impact of different time series aggregation methods on optimal energy system design. Renewable Energy 2018;117:474-87. https://doi.org/10.1016/j.renene.2017.10.017.

[397] Nahmmacher P, Schmid E, Hirth L, Knopf B. Carpe diem: A novel approach to select representative days for long-term power system modeling. Energy 2016;112:430-42. https://doi.org/10.1016/j.energy.2016.06.081.

[398] Rai V, Robinson SA. Agent-based modeling of energy technology adoption: Empirical integration of social, behavioral, economic, and environmental factors. Environmental Modelling \& Software 2015;70:163-77. https://doi.org/10.1016/j.envsoft.2015.04.014.

[399] Scheller F, Johanning, S., Bruckner, T. A review of designing empirically grounded agent-based models of innovation diffusion: Development process, conceptual foundation and research agenda. [February 05, 2020]; Available from: https://www.econstor.eu/handle/10419/191981.

[400] Selvakkumaran S, Ahlgren E. Model-Based Exploration of Co-Creation Efforts: The Case of Solar Photovoltaics (PV) in Skåne, Sweden. Sustainability 2018;10(11):3905. https://doi.org/10.3390/su10113905.

[401] McKenna R. The double-edged sword of decentralized energy autonomy. Energy Policy 2018;113:747-50. https://doi.org/10.1016/j.enpol.2017.11.033.

[402] Pfenninger S, Hawkes A, Keirstead J. Energy systems modeling for twenty-first century energy challenges. Renewable and Sustainable Energy Reviews 2014;33:74-86. https://doi.org/10.1016/j.rser.2014.02.003.

[403] Pfenninger S, Hirth L, Schlecht I, Schmid E, Wiese F, Brown T et al. Opening the black box of energy modelling: Strategies and lessons learned. Energy Strategy Reviews 2018;19:63-71. https://doi.org/10.1016/j.esr.2017.12.002.

[404] DeCarolis J, Daly H, Dodds P, Keppo I, Li F, McDowall W et al. Formalizing best practice for energy system optimization modelling. Applied Energy 2017;194:184-98. https://doi.org/10.1016/j.apenergy.2017.03.001.

[405] Hirth L, Ueckerdt F, Edenhofer O. Integration costs revisited - An economic framework for wind and solar variability. Renewable Energy 2015;74:925-39. https://doi.org/10.1016/j.renene.2014.08.065.

[406] Ueckerdt F, Hirth L, Luderer G, Edenhofer O. System LCOE: What are the costs of variable renewables? Energy 2013;63:61-75. https://doi.org/10.1016/j.energy.2013.10.072.

[407] Nolden C, Schönfelder M, Eßer-Frey A, Bertsch V, Fichtner W. Network constraints in techno-economic energy system models: Towards more accurate modeling of power flows in long-term energy system models. Energy Syst 2013;4(3):267-87. https://doi.org/10.1007/s12667-013-0078-0.

[408] Chaudry M, Jenkins N, Qadrdan M, Wu J. Combined gas and electricity network expansion planning. Applied Energy 2014;113:1171-87. https://doi.org/10.1016/j.apenergy.2013.08.071.

[409] Brown T, Schlachtberger D, Kies A, Schramm S, Greiner M. Synergies of sector coupling and transmission reinforcement in a costoptimised, highly renewable European energy system. Energy 2018;160:720-39. https://doi.org/10.1016/j.energy.2018.06.222. 
[410] Jägemann C, Hagspiel S, Lindenberger D. The economic inefficiency of grid parity: The case of German photovoltaics: EWI Working Paper. [October 29, 2019]; Available from: https://www.econstor.eu/bitstream/10419/92970/1/775175242.pdf. 


\title{
Working Paper Series in Production and Energy
}

\author{
recent issues
}

No. 40 Jann Weinand, Sabrina Ried, Max Kleinebrahm, Russell McKenna, Wolf Fichtner: Identification of potential off-grid municipalities with $100 \%$ renewable energy supply

No. 39 Rebekka Volk, Christian Kern, Frank Schultmann: Secondary raw material markets in the C\&D sector: Study on user acceptance in southwest Germany

No. 38 Christoph Fraunholz, Dirk Hladik, Dogan Keles, Dominik Möst, Wolf Fichtner: On the Long-Term Efficiency of Market Splitting in Germany

No. 37 Christoph Fraunholz, Dogan Keles, Wolf Fichtner: On the Role of Electricity Storage in Capacity Remuneration Mechanisms

No. 36 Hansjörg Fromm, Lukas Ewald, Dominik Frankenhauser, Axel Ensslen, Patrick Jochem: A Study on Free-floating Carsharing in Europe Impacts of car2go and DriveNow on modal shift, vehicle ownership, vehicle kilometers traveled, and $\mathrm{CO}_{2}$ emissions in 11 European cities

No. 35 Florian Zimmermann, Andreas Bublitz, Dogan Keles, Wolf Fichtner: Cross-border effects of capacity remuneration mechanisms: the Swiss case

No. 34 Judith Auer: Ladeinfrastruktur für Elektromobilität im Jahr 2050 in Deutschland

No. 33 Jann Weinand, Max Kleinebrahm, Russell McKenna, Kai Mainzer, Wolf Fichtner: Developing a three-stage heuristic to design geothermalbased district heating systems

No. 32 Daniel Fehrenbach: Modellgestützte Optimierung des energetischen Eigenverbrauchs von Wohngebäuden bei sektor-gekoppelter Wärmeversorgung -Vorstellung des POPART-Modells

No 31 Jann Weinand, Russell McKenna, Katharina Karner, Lorenz Braun, Carsten Herbes: Assessing the potential contribution of excess heat from biogas plants towards decarbonising German residential heating

No. 30 Daniel Heinz: Erstellung und Auswertung repräsentativer Mobilitätsund Ladeprofile für Elektrofahrzeuge in Deutschland

No. 29 Alexander Harbrecht, Russell McKenna, David Fischer, Wolf Fichtner: Behavior-oriented Modeling of Electric Vehicle Load Profiles: A Stochastic Simulation Model Considering Different Household Characteristics, Charging Decisions and Locations

No. 28 Felix Hübner, Sven Möller, Frank Schultmann: Entwicklung eines Expertensystems für die Planung kerntechnischer Rückbauprojekte

The responsibility for the contents of the working papers rests with the author, not the institute. Since working papers are of preliminary nature, it may be useful to contact the author of a particular working paper about results or caveats before referring to, or quoting, a paper. Any comments on working papers should be sent directly to the author. 


\section{Impressum}

Karlsruher Institut für Technologie

Institut für Industriebetriebslehre und Industrielle Produktion (IIP) Deutsch-Französisches Institut für Umweltforschung (DFIU)

Hertzstr. 16

D-76187 Karlsruhe

KIT - Universität des Landes Baden-Württemberg und

nationales Forschungszentrum in der Helmholtz-Gemeinschaft

Working Paper Series in Production and Energy

No. 41, April

ISSN 2196-7296 